\title{
Curcumin induces regeneration of $\beta$ cells and suppression of phosphorylated-NF-kB in streptozotocin-induced diabetic mice
}

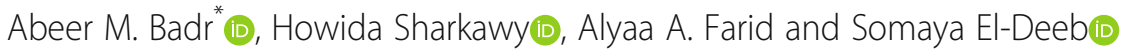

\begin{abstract}
Objectives: This study aimed to assess the immunomodulatory effect of curcumin on innate and adaptive immune responses, as well as its inhibitory power on hyperglycemia in streptozotocin (STZ)-induced diabetic CD1 mice.

Material and methods: Mice were divided into six groups as follows: normal control mice (I), mice were intraperitoneally (i.p.) injected with either citrate (II), DEMSO (III), or curcumin (170 mg/kg, 3 times/week, for 28 days) (IV), as well as a single intraperitoneal injection of STZ $(160 \mathrm{mg} / \mathrm{kg})(\mathrm{V})$ and STZ mice treated with curcumin (VI). The anti-diabetic effect was assessed by estimation of the blood glucose concentration on days 3, 10, 17, 24, and 31. Differential count of white blood cells and the levels of cytokines were also measured at all previous time points. Pancreatic islets were examined for histopathological changes, and the immunohistochemical analysis for insulin and phosphorylated-nuclear factor-kappa B (phospho-NF-KB) was done at the end of the study.
\end{abstract}

Results: After curcumin administration, hyperglycemia was improved compared to diabetic mice; however, glucose concentration remains above the normal level. Treatment with curcumin selectively increased the count of lymphocytes and monocytes but decreased the granulocyte count in STZ diabetic mice. Diabetic mice treated with curcumin showed lower levels of interferon (IFN)- $\gamma$, interleukin (IL)-6, and IL-1 $\beta$, as well as a higher level of IL-2 than in diabetic mice. Histopathological alterations that accompanied diabetes induction were ameliorated after curcumin administration. The pancreatic islets of treated diabetic mice displayed a decline in the immunostaining positivity of phospho-NF-kB compared to diabetic mice.

Conclusion: These results suggest that curcumin has anti-diabetic properties as it can improve the damage caused to the pancreatic $\beta$ cells by its preferential immunomodulatory action on T helper1-related cytokines, as well as the immunosuppressive activity on proinflammatory cytokines.

Keywords: Streptozotocin, Diabetes: Cytokines, Immune response, Pancreatic islets, $\beta$ cells, Phospho-NF-kB, Inflammation, Hyperglycemia

\section{Introduction}

Diabetes mellitus (DM) is a chronic metabolic disease, which is characterized by hyperglycemia due to the defect in insulin secretion or resistance to insulin action (Tremblay \& Hamet, 2019). Endocrine pancreas tissue contains Langerhans islets that consist mainly of $\beta$ cells, whose function is to synthesize and secrete insulin that

\footnotetext{
* Correspondence: abeerbadr@gmail.com

Zoology Department, Faculty of Science, Cairo University, Giza 12613, Egypt
}

plays a key role in the regulation of glucose homeostasis (Rojas et al., 2018). Type 1 diabetes (T1D) is an autoimmune disease that often affects people with genetic susceptibility and younger years of age. T1D is characterized by the unique destruction and distinctive loss of the total mass of $\beta$ cells by $\mathrm{T}$ lymphocytes and autoantibodies (Tosone, Maraolo, Palmiero, Mascolo, \& Orlando, 2013) that leading to functional impairment and total inability to synthesize insulin by the pancreas (Kaul, Apostolopoulou, \& Roden, 2015).
Springer Open (c) The Author(s). 2020 Open Access This article is licensed under a Creative Commons Attribution 4.0 International License which permits use, sharing, adaptation, distribution and reproduction in any medium or format, as long as you give appropriate credit to the original author(s) and the source, provide a link to the Creative Commons licence, and indicate if changes were made. The images or other third party material in this article are included in the article's Creative Commons licence, unless indicated otherwise in a credit line to the material. If material is not included in the article's Creative Commons licence and your intended use is not permitted by statutory regulation or exceeds the permitted use, you will need to obtain permission directly from the copyright holder. To view a copy of this licence, visit http://creativecommons.org/licenses/by/4.0/. 
During T1D pathogenesis, the recruitment of inflammatory cells to Langerhans islets contributes to the development of proinflammatory cytokines such as tumor necrosis factor (TNF)- $\alpha$, interferon (IFN)- $\gamma$, and interleukin (IL)-1 $\beta$. These cytokines are important mediators for the primary destruction of pancreatic $\beta$ cells (Eizirik, Colli, \& Ortis, 2009) by triggering intracellular signalization pathways that lead to the proapoptotic mechanism (Pirot, Cardozo, \& Eizirik, 2008). The excess secretion of such cytokines stimulates the nuclear factor kappa-light-chainenhancer (NF-kB) of activated $\beta$ cells, expression of inducible nitric oxide synthase (iNOS), and NO generation that is involved in the death of pancreatic cells (Csorba, Lyon, \& Hollenberg, 2010). Upon NF-kB phosphorylation, it binds DNA and contributes to proinflammatory cytokine transcription. Therefore, phosphorylated p65 subunit of NF- $\mathrm{KB}$ is considered being a functional measure of its activation (Okazaki et al., 2003).

Due to the growth in the number of people diagnosed with diabetes worldwide every year, strong demand for the use of natural products in the treatment of DM or secondary complications is being made.

Turmeric (Curcuma longa Linn.) of the ginger family (Zingiberaceae) is known as one of South East Asia's predominantly used dietary spice plants (Grynkiewicz \& Ślifirski, 2012). Curcuminoid is a yellow-orange powder, that is extracted from the rhizome of the herb and forms the major component of turmeric. Curcumin (diferuloylmethane) is the main active constituent of curcuminoid that is used in the traditional medicine overall world (Karfowicz-bodalska, Han, Freier, Smole-ski, \& Bodalska, 2017). It has antidiabetic, antioxidant, anti-inflammatory, and anti-cancerous effects based on its crucial biological and pharmacological activities (Kazazis, G. Vallianou, Kollas, \& Evangelopoulos, 2014; Meng, Li, \& Cao, 2013). Curcumin has been known to reduce hyperglycemia and hyperlipidemia and to improve diabetic problems (Blaslov, 2017). Sevaral studies have assessed the role of curcumin in signal transduction pathways associated with inflammation (Kahkhaie et al., 2019).

We hypothesized that the function and number of $\beta$ cells could be affected preferentially by curcumin. Therefore, the present work was designed to assess the effect of curcumin on hyperglycemia in streptozotocin (STZ)-induced diabetic mice and its impact on the balance of $\mathrm{T}$ helper (Th)-related cytokines. Moreover, it aimed to investigate the possible improvement action of curcumin on the alterations that accompanied the pancreatic islets and evaluate the expression of both insulin and phosphorylation of transcriptional NF-kB-p65.

\section{Materials and methods}

\section{Ethical considerations}

All animal procedures and the experimental protocols were carried out according to the internationally valid guidelines and ethical conditions. The study is approved by the institutional animal care and use committee (IACUC) (approval no. GUFS/S/PHY/12/14) at the Faculty of Science, Cairo University (Egypt), according to the World Organization for Animal Health (OIE) and Guide for the Care and Use of Laboratory Animals $8^{\text {th }}$ edition, 2011.

\section{Animals}

Male CD1 mice weighed $22 \pm 3 \mathrm{~g}$ and obtained from the animal house of the National Research Center. They were housed under standard laboratory care $\left(22 \pm 2{ }^{\circ} \mathrm{C}\right.$, $45-55 \%$ humidity) on a12-h light/dark cycle with drinking water ad labitum and $24 \%$ protein and $4 \%$ fat diet.

\section{Induction of diabetic mice}

Mice were acclimatized for 1 week before the experiment initiation. After 12-h fasting, diabetes was induced by a single intraperitoneal injection of freshly prepared STZ (S0130-1G, LoT\#031M1287V, Sigma-Aldrich, USA) (160 $\mathrm{mg} / \mathrm{kg}$ of body weight) (Aldahmash, El-Nagar, \& Ibrahim, 2016; Deeds et al., 2011). STZ solution was prepared by dissolving STZ powder in $0.1 \mathrm{M}$ citrate buffer and was stored in a sterile tube on ice. Citrate buffer was prepared by mixing $2: 3$ of $0.1 \mathrm{M} \mathrm{Na}$ citrate and $0.1 \mathrm{M}$ of citric acid (pH 4). The animals were permitted to drink $10 \%$ glucose solution overnight to prevent initial STZ-induced hypoglycemic mortality. The blood glucose was monitored on the third day; mice with fasting blood glucose levels > $200 \mathrm{mg} / \mathrm{dl}$ were considered diabetic (Sun et al., 2016), and it was considered the starting point of the treatment.

\section{Study design}

Curcumin was dissolved in dimethylsulfoxide (DMSO) (extra pure C2H6OS.M $=78.13, D=1.109 / \mathrm{CM} 3$ ) and intraperitoneally (i.p.) injected $(170 \mathrm{mg} / \mathrm{kg} /$ day $)$ three times weekly for 28 days (Tamaddonfard, Erfanparast, Hamzeh-Gooshchi, \& Yousofizadeh, 2012). Animals were divided into six groups, 25 per each group: group I, normal mice; group II (vehicle control), mice were i.p. injected once with citrate buffer as a solvent of STZ; group III (vehicle control), mice were i.p. injected with DMSO three times weekly for 28 days as a solvent of curcumin; and group IV, mice were injected i.p. with curcumin three times weekly for 28 days. In the last two groups, mice were injected once with STZ $(160 \mathrm{mg} / \mathrm{kg}$ of body weight) (positive control) (group V), and group VI was treated after that with curcumin three times weekly for 28 days and served as the treated group. From each group, five mice were euthanized on days 3, 10, 17, 24, and 31 . Mice were anesthetized by $5 \%$ isoflurane; the blood was collected by cardiac puncture. Death is confirmed by cervical dislocation. Blood samples were used 
to measure differential white blood cells (WBCs) count and cytokine levels.

\section{Measurement of blood glucose}

Mice tail was snipped by a sharp razor to collect blood, and the blood glucose level was measured immediately by glucose strips (Haemo-glucotest).

\section{White blood cell analysis}

A differential count of WBCs was done by using an automated Hematology Analyzer (HA-vet Clindiag, Clindiag Systems B.V.B.A).

\section{Estimation of cytokine assays}

The plasma levels (IL-1 $\beta$, IFN- $\gamma$, IL-2, and IL-6) were measured by mouse solid-phase sandwich enzyme linked-immunosorbent assay (ELISA) kits (Invitrogen, Life Technologies, USA). Briefly, a coated 96-well ELISA plate with anti-mouse IL-1 $\beta$ was directly incubated with the standard, plasma samples, and the detection antibody for $1 \mathrm{~h}$ at $37^{\circ} \mathrm{C}$. A coated 96-well ELISA plate with either anti-mouse IFN- $\gamma$, IL-2, or IL-6 was incubated with the standard and plasma samples at $37^{\circ} \mathrm{C}$. Then, biotinylated biotin conjugate solution was added after washing and incubated at $37^{\circ} \mathrm{C}$ for $30 \mathrm{~min}, 1 \mathrm{~h}$, and $2 \mathrm{~h}$ in case of IL-6, IFN- $\gamma$, and IL-2, respectively. After washing, streptavidin-HRP conjugate was added to each well and incubated for $30 \mathrm{~min}$ at $37^{\circ} \mathrm{C}$. Finally, the plates were washed, and the colored complex was developed by using stabilized chromogen and incubated for $30 \mathrm{~min}$ at $37^{\circ} \mathrm{C}$ in the dark. The reaction was stopped by adding sulphuric acid that changes the color in the wells from blue to yellow. The absorbance is read at $450 \mathrm{~nm}$ with a microtiter plate reader (Das, Italy). The concentration of an unknown cytokine was calculated by a standard curve fitting software, and the concentration was expressed as picograms per milliliter.

\section{Histological examination}

Pancreas tissue was washed with ice-chilled phosphate buffer saline (PBS) (0.1 M, pH 7.4), fixed immediately for $48 \mathrm{~h}$ in $10 \%$ formaldehyde, and embedded in paraffin. Sections with 4-5 $\mu \mathrm{m}$ thickness were stained with hematoxylin and eosin (H\&E) dye. All tissue sections were examined under a light microscope.

\section{Immunohistochemistry staining}

Paraffin blocks were cut into sections and mounted on glass slides. Pancreas sections were deparaffinized in $x y-$ lene and rehydrated through graded alcohols. After that, the sections were incubated in $10 \times$ antigen retrieval (R\&D Systems, Inc., Minneapolis, MN, USA) solution at $95^{\circ} \mathrm{C}$ for $20 \mathrm{~min}$ followed by cooling to room temperature and incubated with $3 \% \mathrm{H}_{2} \mathrm{O}_{2}$ for 15 min to block the endogenous peroxidase activity and washed with PBS ( $\mathrm{pH}$ 7.4) three times. Then, sections were blocked with normal goat serum for $30 \mathrm{~min}$ at room temperature and incubated with the primary antibody rabbit polyclonal anti-mouse phospho-RELA (S536) antibody (phospho-NFkB-p65) (Cusabio, Biotech Co., Ltd.) or insulin rabbit anti-mouse monoclonal antibody (Boster biological, Technology, Pleasanton CA, USA) overnight at $4{ }^{\circ} \mathrm{C}$ in a humidified chamber. The slides were washed with $\mathrm{PBS}$ and incubated with goat anti-rabbit IgG secondary antibody (Abcam, ab6721) conjugated with horseradish peroxidase (HRP) at room temperature for $1 \mathrm{~h}$, followed by washing with PBS. All slides were visualized with 3,3-diaminobenzidine chromogen (SigmaAldrich, Inc., USA) and immersed in Mayer's hematoxylin for counterstaining. At least five random fields were used to detect and localize the immunostaining of the two antibodies for each specimen. All sections were examined by an image analyzer computer system, attached to a light microscope using Leica Qwin 500 software (Leica Imaging Systems Ltd, Cambridge, UK) to determine the immunostaining intensity.

\section{Statistical analysis}

The normality and variance of homogeneity were tested before any statistical analysis. All studied parameters were normally distributed by using a non-parametrical Kolmogorov-Smirnov test. All data were expressed as a mean \pm standard error of the mean (SEM) and have been assessed by SPSS (version 22, IBM, Chicago, IL, USA). Significant differences between the groups were analyzed using one-way analysis of variance (ANOVA), followed by Duncan's post hoc test. Statistical significance is considered at $P<0.05$. The percentage of change was measured by the following formula:

$$
\% \text { of change }=\frac{\text { Mean of treated }- \text { Mean of control group }}{\text { Mean of control }} \times 100
$$

\section{Results}

\section{Effect of curcumin on blood glucose levels}

After injection with STZ, the mean values of blood glucose levels in STZ diabetic mice remained above 200 $\mathrm{mg} / \mathrm{dl}$ during the entire experimental period; these levels were significantly $(P<0.05)$ higher levels than those observed in normal mice. The percentage increase in blood glucose in STZ diabetic mice was reduced by $121.14 \%$ on day 31. Treatment of STZ diabetic mice with curcumin caused a significant reduction $(P<0.05)$ in the values of blood glucose level compared to STZ diabetic mice starting from the 24th to the 31st day (Table 1). 
Table 1 Blood glucose levels $(\mathrm{mg} / \mathrm{dl})$ in the experimental groups at the experimental periods

\begin{tabular}{|c|c|c|c|c|c|}
\hline \multirow{2}{*}{$\begin{array}{l}\text { Experimental } \\
\text { groups }\end{array}$} & \multicolumn{5}{|c|}{ Experimental periods (days) } \\
\hline & 3 & 10 & 17 & 24 & 31 \\
\hline I & $142.6 \pm 2.50^{\mathbf{B a}}$ & $145.8 \pm 4.62^{\mathbf{A a}}$ & $147 \pm 3.49^{\mathbf{A B a}}$ & $146.2 \pm 2.13^{\mathbf{A B a}}$ & $140.00 \pm 3.03^{\mathbf{A a}}$ \\
\hline$\|$ & $138.4 \pm 1.89^{\mathrm{Ba}}$ & $129.2 \pm 3.61^{\mathrm{Aa}}$ & $159.6 \pm 5.12^{\mathbf{A B b}}$ & $134.4 \pm 2.87^{\mathrm{ABa}}$ & $131.40 \pm 3.79^{\mathbf{A a}}$ \\
\hline$\%$ of change $\mathrm{P}^{\mathrm{P} 1}$ & $(-2.94)$ & $(-11.38)$ & $(8.57)$ & $(-8.07)$ & $(-6.14)$ \\
\hline III & $123.2 \pm 3.34^{\mathrm{Ba}}$ & $142.6 \pm 9.78^{\mathbf{A b c}}$ & $167.2 \pm 6.48^{\mathrm{ABCd}}$ & $128 \pm 4.87^{\mathbf{A B a b}}$ & $151.40 \pm 2.50^{\mathbf{A b}}$ \\
\hline$\%$ of change $\mathrm{P}^{\mathrm{P} 1}$ & $(13.60)$ & $(-2.19)$ & $(13.74)$ & $(-12.44)$ & -8.14 \\
\hline IV & $110 \pm 4.43^{\mathrm{Aa}}$ & $145.6 \pm 9.97^{\mathbf{A b}}$ & $130.2 \pm 5.26^{\mathbf{A b}}$ & $122.8 \pm 4.77^{\mathbf{A b}}$ & $127.20 \pm 6.56^{\text {Aab }}$ \\
\hline$\%$ of change ${ }^{\mathrm{P} 1}$ & $(-22.72)$ & $(-0.137)$ & $(-11.428)$ & $(-16)$ & $(-9.14)$ \\
\hline V & $315.40 \pm 14.49^{\mathrm{Ca}}$ & $289.40 \pm 17^{\mathrm{Ba}}$ & $294.40 \pm 35.9^{\mathbf{B a}}$ & $266.00 \pm 13.5^{\mathrm{Ca}}$ & $309.60 \pm 28.76^{\mathrm{Ca}}$ \\
\hline$\%$ of change ${ }^{\mathrm{P} 1}$ & $(121.18)$ & (98.49) & $(100.27)$ & $(81.94)$ & $(121.14)$ \\
\hline $\mathrm{Vl}$ & $299.60 \pm 17.48^{\mathrm{Cb}}$ & $283.60 \pm 11.64^{\mathbf{B b}}$ & $259.20 \pm 15.76^{\text {Bab }}$ & $210.60 \pm 13.59^{\mathbf{B a}}$ & $231.40 \pm 9.11^{\mathrm{Ba}}$ \\
\hline$\%$ of change ${ }^{P 2}$ & $(-5.01)$ & $(-2.00)$ & $(-11.96)$ & $(-20.82)$ & $(-25.25)$ \\
\hline
\end{tabular}

Data were expressed as a mean of 5 mice \pm standard error of the mean (SEM)

In rows (small letters) and columns (capital letters), values marked with the same small and capital superscript letters are similar (insignificant, $P \geq 0.05)$ and are significant $(P<0.05)$, respectively. ${ }^{P 1, P 2}$ Percentage of change in comparison with the corresponding groups I and $\mathrm{V}$, respectively

\section{Effect of curcumin on the differential count of white blood cells}

STZ diabetic mice exhibited a slight decrease in the WBC count compared to normal mice during the experimental periods. Their treatment with curcumin stimulated an elevation in the WBCs count on days 17 and 31 (Table 2). The administration of curcumin showed a suppressive effect on the count of lymphocytes $\left(10^{9} / 1\right)$ compared to both normal mice and STZ diabetic mice, reaching significant differences $(P<0.05)$ on day 31 (Table 3). On the other hand, STZ diabetic mice displayed a lower number of monocytes compared to normal mice, reaching a significant level on day 31 . Treatment of diabetic mice with curcumin recorded a higher count of monocytes started from day 17, reaching significant values on day 31 (Table 4). Granulocyte count was increased significantly $(P<0.05)$ in STZ diabetic mice in comparison with normal mice among all days of the investigation, while STZ diabetic mice treated with curcumin exhibited significantly $(P<0.05)$ lower count of granulocytes than those in STZ-induced diabetic mice at most days' time points (Table 5).

\section{Effect of curcumin on the plasma level of interleukin- 6}

IL-6 is an important cytokine with a double face. The STZ group recorded a significantly higher level of IL-6 compared to normal mice at all experimental periods; the highest increase was $106.66 \%$ on day 17 . Treatment

Table 2 WBCs count $\left(10^{9} / \mathrm{L}\right)$ in the experimental groups at the experimental periods

\begin{tabular}{|c|c|c|c|c|c|}
\hline \multirow{2}{*}{$\begin{array}{l}\text { Experimental } \\
\text { groups }\end{array}$} & \multicolumn{5}{|c|}{ Experimental periods (days) } \\
\hline & 3 & 10 & 17 & 24 & 31 \\
\hline I & $4.93 \pm 0.06^{\mathbf{B a}}$ & $5.18 \pm 0.17^{\mathrm{Aa}}$ & $4.96 \pm 0.08^{\mathbf{B a}}$ & $5.48 \pm 0.47^{\mathbf{A a}}$ & $5.76 \pm 0.29^{\mathbf{B a}}$ \\
\hline$\|$ & $4.88 \pm 0.21^{\mathrm{Ba}}$ & $4.79 \pm 0.14^{\mathrm{Aa}}$ & $4.84 \pm 0.38^{\mathbf{B a}}$ & $4.82 \pm 0.22^{\mathbf{A a}}$ & $5.56 \pm 0.32^{\mathrm{Ba}}$ \\
\hline$\%$ of change $\mathrm{e}^{\mathrm{P} 1}$ & $(-1.01)$ & $(-7.41)$ & $(-2.30)$ & $(-12.04)$ & $(-3.41)$ \\
\hline III & $4.57 \pm 0.30^{\mathbf{A B a}}$ & $5.38 \pm 0.19^{\mathbf{A b}}$ & $4.74 \pm 0.17^{\mathrm{Bab}}$ & $4.83 \pm 0.27^{\text {Aab }}$ & $4.33 \pm 0.16^{\mathrm{Aa}}$ \\
\hline$\%$ of change ${ }^{\mathrm{P} 1}$ & $(-7.38)$ & (3.78) & $(-4.32)$ & $(-11.86)$ & $(-24.74)$ \\
\hline IV & $4.75 \pm 0.46^{\mathrm{Ba}}$ & $4.91 \pm 0.24^{\text {Aab }}$ & $5.81 \pm 0.44^{\mathrm{cb}}$ & $5.32 \pm 0.18^{\text {Aab }}$ & $5.88 \pm 0.2^{\mathbf{B b}}$ \\
\hline$\%$ of change ${ }^{P 1}$ & $(-3.69)$ & $(-5.21)$ & $(17.31)$ & $(-2.92)$ & $(2.29)$ \\
\hline V & $4.46 \pm 0.31^{\mathrm{ABa}}$ & $5 \pm 0.80^{\mathbf{A a}}$ & $3.86 \pm 0.25^{\mathrm{Aa}}$ & $4.9 \pm 0.57^{\mathrm{Aa}}$ & $4.25 \pm 0.12^{\mathrm{Aa}}$ \\
\hline$\%$ of change $\mathrm{P}^{\mathrm{P} 1}$ & $(-9.53)$ & $(-3.48)$ & $(-22.16)$ & $(-10.58)$ & $(-26.20)$ \\
\hline $\mathrm{Vl}$ & $3.82 \pm 0.22^{\mathrm{Aa}}$ & $4.78 \pm 0.12^{\mathbf{A b}}$ & $5.22 \pm 0.23^{\mathrm{BCbc}}$ & $5.89 \pm 0.17^{\mathbf{A c}}$ & $5.64 \pm 0.39^{B \mathbf{C}}$ \\
\hline$\%$ of change ${ }^{P 2}$ & $(-14.26)$ & $(-4.40)$ & $(35.30)$ & $(20.37)$ & $(32.78)$ \\
\hline
\end{tabular}

Data were expressed as a mean of 5 mice \pm standard error of the mean (SEM)

In rows (small letters) and columns (capital letters), values marked with the same small and capital superscript letters are similar (insignificant, $P \geq 0.05$ ) and are significant $(P<0.05)$, respectively. ${ }^{P 1, P 2}$ Percentage of change in comparison with the corresponding groups I and $V$, respectively 
Table 3 Lymphocyte count $\left(10^{9} / \mathrm{L}\right)$ in the experimental groups at the experimental periods

\begin{tabular}{|c|c|c|c|c|c|}
\hline \multirow{2}{*}{$\begin{array}{l}\text { Experimental } \\
\text { groups }\end{array}$} & \multicolumn{5}{|c|}{ Experimental periods (days) } \\
\hline & 3 & 10 & 17 & 24 & 31 \\
\hline I & $3.92 \pm 0.05^{\mathrm{Ca}}$ & $4.09 \pm 0.16^{\mathbf{A a}}$ & $3.93 \pm 0.08^{\mathrm{BCa}}$ & $4.31 \pm 0.37^{\mathbf{B a}}$ & $4.6 \pm 0.23^{\mathrm{Ba}}$ \\
\hline$\|$ & $3.79 \pm 0.15^{\mathrm{BCa}}$ & $3.73 \pm 0.13^{\mathrm{Aa}}$ & $3.78 \pm 0.28^{\mathrm{Ba}}$ & $3.9 \pm 0.23^{\mathrm{ABa}}$ & $4.34 \pm 0.27^{\mathrm{Ba}}$ \\
\hline$\%$ of change ${ }^{P_{1}}$ & $(-3.27)$ & $(-8.83)$ & $(-3.86)$ & $(-9.56)$ & $(-5.66)$ \\
\hline III & $3.48 \pm 0.24^{\mathrm{ABCa}}$ & $3.79 \pm 0.31^{\mathrm{Aa}}$ & $3.61 \pm 0.099^{\mathrm{Ba}}$ & $3.69 \pm 0.214^{\mathrm{ABa}}$ & $3.3 \pm 0.14^{\mathrm{Aa}}$ \\
\hline$\%$ of change $\mathrm{P}^{\mathrm{P} 1}$ & $(-11.28)$ & $(-7.29)$ & $(-8.30)$ & $(-14.50)$ & $(-28.46)$ \\
\hline IV & $3.69 \pm 0.36^{\mathrm{BCa}}$ & $3.82 \pm 0.17^{\text {Aab }}$ & $4.55 \pm 0.34^{\mathrm{Cb}}$ & $4.17 \pm 0.13^{\text {ABab }}$ & $4.63 \pm 0.16^{\mathrm{Bb}}$ \\
\hline$\%$ of change $\mathrm{e}^{\mathrm{P} 1}$ & $(-5.85)$ & $(-6.53)$ & $(15.82)$ & $(-3.19)$ & $(0.51)$ \\
\hline V & $3.13 \pm 0.22^{\mathrm{ABa}}$ & $3.47 \pm 0.57^{\mathrm{Aa}}$ & $2.68 \pm 0.17^{\mathrm{Aa}}$ & $3.38 \pm 0.39^{\mathbf{A a}}$ & $2.99 \pm 0.08^{\mathbf{A a}}$ \\
\hline$\%$ of change ${ }^{\mathrm{P} 1}$ & $(-20.20)$ & $(-15.10)$ & $(-31.84)$ & $(-21.56)$ & $(-34.85)$ \\
\hline $\mathrm{Vl}$ & $2.94 \pm 0.17^{\mathrm{Aa}}$ & $3.68 \pm 0.09^{\mathbf{A b}}$ & $4.01 \pm 0.17^{\mathrm{BCbc}}$ & $4.54 \pm 0.13^{B c}$ & $4.34 \pm 0.3^{B C}$ \\
\hline$\%$ of change ${ }^{P 2}$ & $(-5.96)$ & $(5.82)$ & $(49.86)$ & (34.10) & $(44.78)$ \\
\hline
\end{tabular}

Data were expressed as a mean of 5 mice \pm standard error of the mean (SEM)

In rows (small letters) and columns (capital letters), values marked with the same small and capital superscript letters are similar (insignificant, $P \geq 0.05)$ and are significant $(P<0.05)$, respectively. ${ }^{P 1, P 2}$ Percentage of change in comparison with the corresponding groups I and $\mathrm{V}$, respectively

of diabetic mice with curcumin reduced the level of IL-6 significantly compared to diabetic mice at all experimental periods (Table 6).

\section{Effect of curcumin on the levels of interleukin- $1 \beta$}

STZ diabetic mice displayed a significantly higher level of IL-1 $\beta$ compared to normal mice. Treatment with curcumin significantly decreased the level of IL$1 \beta$ compared with diabetic mice from day 10 to 31 (Table 7).

\section{Effect of curcumin on the levels of interleukin-2} Induction of diabetic mice with STZ revealed a significant decrease in the level of IL-2 compared to normal mice, starting from the 10th to the 31st day (Table 8). Curcumin administration induced significantly higher levels of IL-2 compared to STZ diabetic mice on days 24 and 31.

\section{Effect of curcumin on the levels of interferon- $\gamma$}

IFN- $\gamma$ production was significantly increased in STZ diabetic mice from the 3rd to the 31st day compared to normal mice, recording the highest percentage of increase $(80.22 \%)$ in the early stages of induction. Treatment of STZ diabetic mice with curcumin caused a significant reduction in the levels of IFN- $\gamma$ compared to normal mice from the 10th to the 31st day (Table 9).

Table 4 Monocyte count $\left(10^{9} / \mathrm{L}\right)$ in the experimental groups at the experimental periods

\begin{tabular}{|c|c|c|c|c|c|}
\hline \multirow{2}{*}{$\begin{array}{l}\text { Experimental } \\
\text { groups }\end{array}$} & \multicolumn{5}{|c|}{ Experimental periods (days) } \\
\hline & 3 & 10 & 17 & 24 & 31 \\
\hline I & $0.5 \pm 0.01^{\mathrm{Ba}}$ & $0.53 \pm 0.02^{\mathrm{Aa}}$ & $0.48 \pm 0.02^{\mathrm{ABa}}$ & $0.56 \pm 0.05^{\mathrm{Aa}}$ & $0.54 \pm 0.04^{\mathrm{BCa}}$ \\
\hline$\|$ & $0.49 \pm 0.02^{\mathrm{Ba}}$ & $0.48 \pm 0.01^{\mathrm{Aa}}$ & $0.48 \pm 0.02^{\mathrm{ABa}}$ & $0.50 \pm 0.03^{\mathrm{Aa}}$ & $0.56 \pm 0.03^{\mathrm{BCa}}$ \\
\hline$\%$ of change ${ }^{P 1}$ & $(-2.92)$ & $(-7.31)$ & $(-0.98)$ & $(-10.29)$ & $(2.58)$ \\
\hline III & $0.50 \pm 0.03^{\mathbf{B a}}$ & $0.55 \pm 0.04^{\mathrm{Aa}}$ & $0.52 \pm 0.039^{\mathrm{BCa}}$ & $0.53 \pm 0.03^{\mathrm{Aa}}$ & $0.47 \pm 0.02^{\mathbf{A B a}}$ \\
\hline$\%$ of change ${ }^{P_{1}}$ & $(-0.09)$ & (3.90) & $(6.07)$ & $(-5.05)$ & $(-13.59)$ \\
\hline IV & $0.46 \pm 0.04^{\mathrm{ABa}}$ & $0.49 \pm 0.02^{\text {Aab }}$ & $.60 \pm 0.51^{\mathrm{cb}}$ & $0.54 \pm 0.02^{\text {Aab }}$ & $0.60 \pm 0.02^{\mathbf{C b}}$ \\
\hline$\%$ of change ${ }^{P_{1}}$ & $(-7.62)$ & $(-6.80)$ & (22.44) & $(-3.15)$ & $(8.64)$ \\
\hline V & $0.45 \pm 0.03^{\mathrm{ABa}}$ & $0.50 \pm 0.08^{\mathrm{Aa}}$ & $0.40 \pm 0.03^{\mathbf{A a}}$ & $0.51 \pm 0.07^{\mathrm{Aa}}$ & $0.42 \pm 0.01^{\mathbf{A a}}$ \\
\hline$\%$ of change ${ }^{P 1}$ & $(-11.28)$ & $(-5.09)$ & $(-17.17)$ & $(-8.58)$ & $(-23.22)$ \\
\hline $\mathrm{Vl}$ & $0.40 \pm 0.20^{\mathrm{Aa}}$ & $0.48 \pm 0.01^{\mathbf{A b}}$ & $0.52 \pm 0.02^{\mathrm{BCbc}}$ & $0.59 \pm 0.02^{\mathrm{Ac}}$ & $0.56 \pm 0.04^{\mathrm{cc}}$ \\
\hline$\%$ of change ${ }^{P 2}$ & $(-14.26)$ & $(-4.4)$ & (29.79) & $(15.29)$ & (35.53) \\
\hline
\end{tabular}

Data were expressed as a mean of 5 mice \pm standard error of the mean (SEM)

In rows (small letters) and columns (capital letters), values marked with the same small and capital superscript letters are similar (insignificant, $P \geq 0.05$ ) and are significant $(P<0.05)$, respectively. ${ }^{P 1, P 2}$ Percentage of change in comparison with the corresponding groups $I$ and $V$, respectively 
Table 5 Granulocyte count $\left(10^{9} / \mathrm{L}\right)$ in the experimental groups at the experimental periods

\begin{tabular}{|c|c|c|c|c|c|}
\hline \multirow{2}{*}{$\begin{array}{l}\text { Experimental } \\
\text { groups }\end{array}$} & \multicolumn{5}{|c|}{ Experimental periods (days) } \\
\hline & 3 & 10 & 17 & 24 & 31 \\
\hline I & $0.54 \pm 0.01^{\mathrm{Aa}}$ & $0.57 \pm 0.02^{\mathrm{Aa}}$ & $0.54 \pm 0.01^{\mathrm{Aa}}$ & $0.60 \pm 0.05^{\mathrm{Aa}}$ & $0.63 \pm 0.03^{\mathrm{ABa}}$ \\
\hline$\|$ & $0.59 \pm 0.03^{\mathrm{Aa}}$ & $0.57 \pm 0.02^{\mathrm{Aa}}$ & $0.58 \pm 0.04^{\mathrm{ABa}}$ & $0.60 \pm 0.04^{\mathrm{Aa}}$ & $0.66 \pm 0.04^{\mathrm{Ba}}$ \\
\hline$\%$ of change $\mathrm{P}^{\mathrm{P} 1}$ & (7.99) & $(1.00)$ & $(6.58)$ & $(-0.07)$ & $(5.38)$ \\
\hline III & $0.59 \pm 0.04^{\mathrm{Aa}}$ & $.69 \pm 0.03^{\mathbf{A b}}$ & $0.62 \pm 0.02^{\mathrm{ABab}}$ & $0.63 \pm 0.04^{\text {Aab }}$ & $0.56 \pm 0.02^{\mathrm{Aa}}$ \\
\hline$\%$ of change $\mathrm{e}^{\mathrm{P} 1}$ & $(9.46)$ & $(22.65)$ & (13.08) & $(4.16)$ & $(-11.06)$ \\
\hline IV & $0.57 \pm 0.05^{\mathrm{Aa}}$ & $0.59 \pm 0.03^{\mathrm{Aab}}$ & $0.70 \pm 0.05^{\mathrm{BCb}}$ & $0.64 \pm 0.02^{\text {Aab }}$ & $0.71 \pm 0.03^{\mathrm{Bb}}$ \\
\hline$\%$ of change $\mathrm{e}^{\mathrm{P} 1}$ & $(5.064)$ & $(3.41)$ & (27.98) & (5.91) & $(11.59)$ \\
\hline V & $0.89 \pm 0.06^{\mathrm{Ba}}$ & $1.00 \pm 0.16^{\mathrm{Ba}}$ & $0.77 \pm 0.05^{\mathrm{Ca}}$ & $0.98 \pm 0.11^{\mathrm{Ba}}$ & $0.84 \pm 0.08^{\mathrm{Ca}}$ \\
\hline$\%$ of change $\mathrm{e}^{\mathrm{P} 1}$ & $(64.49)$ & (75.50) & $(41.54)$ & (62.58) & (34.19) \\
\hline $\mathrm{Vl}$ & $0.50 \pm 0.35^{\text {Aa }}$ & $0.62 \pm 0.18^{\mathrm{Ab}}$ & $0.68 \pm 0.03^{\mathrm{BCbc}}$ & $0.76 \pm 0.02^{A c}$ & $0.73 \pm 0.05^{B C}$ \\
\hline$\%$ of change ${ }^{P 2}$ & $(-44.27)$ & $(-37.86)$ & $(-12.05)$ & $(-21.76)$ & $(-13.70)$ \\
\hline
\end{tabular}

Data were expressed as a mean of 5 mice \pm standard error of the mean (SEM)

In rows (small letters) and columns (capital letters), values marked with the same small and capital superscript letters are similar (insignificant, $P \geq 0.05)$ and are significant $(P<0.05)$, respectively. ${ }^{P 1, P 2}$ Percentage of change in comparison with the corresponding groups I and $\mathrm{V}$, respectively

\section{Histological examination of the pancreatic islets and spleen}

The photomicrographs of pancreatic sections of all mouse groups are shown in Fig. 1a-f. The normal group showed a regular outline with the normal structure of Langerhans islets (group I) (Fig. 1a). Sections of the citrate group displayed an irregular outline of the islet glands with a normal appearance in most of the islet glands (group II) (Fig. 1b). Mice of the DMSO group exhibited a regular outline and granulated cytoplasm of the islet glands with small dark nuclei (group III) (Fig. 1c). The normal mice treated with curcumin revealed a regular outline with the normal appearance of the islet glands (group IV) (Fig. 1d). The diabetic group showed destruction of the normal architecture; irregular outline, a size decrease in most of the islet glands, vacuolation of pancreatic acini; and infiltration of mononuclear inflammatory cells in most of the islet cells (group V) (Fig. 1e). Diabetic mice treated with curcumin exhibited an improvement in the islet's morphology as a regular outline in most of the islet cells and vacuolation of some cells of the islet of Langerhans (group VI) (Fig. 1f).

The effect of curcumin on the spleen is shown in Fig. $1 \mathrm{~g}-\mathrm{l}$. The splenic sections of the normal mice showed normal appearance of lymphoid follicles in the white pulp (group I) (Fig. 1g). Most splenic sections of mice groups administered either with citrate (group II) or DMSO (group III) appeared in a normal structure (Fig.

Table 6 Plasma levels of IL-6 $(\mathrm{pg} / \mathrm{ml})$ in the experimental groups at the experimental periods

\begin{tabular}{|c|c|c|c|c|c|}
\hline \multirow{2}{*}{$\begin{array}{l}\text { Experimental } \\
\text { groups }\end{array}$} & \multicolumn{5}{|c|}{ Experimental periods (days) } \\
\hline & 3 & 10 & 17 & 24 & 31 \\
\hline I & $308.00 \pm 4.06^{\mathbf{A a}}$ & $302.20 \pm 4.73^{\mathbf{A a}}$ & $302.80 \pm 3.1^{\mathbf{A a}}$ & $308.20 \pm 5.1^{\mathbf{A a}}$ & $300.80 \pm 2.71^{\mathbf{A a}}$ \\
\hline$\|$ & $324.32 \pm 4.96^{\mathbf{A a}}$ & $311.13 \pm 23.64^{\mathrm{Aa}}$ & $350.04 \pm 13.36^{\mathbf{A B a}}$ & $329.09 \pm 12.47^{\mathbf{A a}}$ & $322.49 \pm 6.34^{\mathrm{Aa}}$ \\
\hline$\%$ of change ${ }^{P 1}$ & $(5.30)$ & $(2.95)$ & $(15.60)$ & $(6.78)$ & $(7.21)$ \\
\hline III & $422.42 \pm 30.22^{\mathbf{B a}}$ & $402.91 \pm 29.47^{\mathbf{B a}}$ & $397.28 \pm 17.67^{\mathbf{B a}}$ & $409.04 \pm 13.65^{\mathrm{Ba}}$ & $393.13 \pm 15.29^{\mathrm{Ba}}$ \\
\hline$\%$ of change $e^{P 1}$ & $(37.15)$ & (33.33) & $(31.20)$ & $(32.72)$ & $(30.69)$ \\
\hline IV & $306.05 \pm 4.56^{\text {Aa }}$ & $489.82 \pm 32.77^{\mathrm{cc}}$ & $460.47 \pm 22.39^{c c}$ & $360.00 \pm 20.37^{\text {ABab }}$ & $381.20 \pm 17.69^{\mathrm{Bb}}$ \\
\hline$\%$ of change ${ }^{P 1}$ & $(-0.63)$ & $(62.08)$ & $(52.07)$ & $(16.81)$ & $(26.73)$ \\
\hline V & $536.96 \pm 31.58^{\mathrm{Ca}}$ & $477.40 \pm 19.1^{\mathrm{Ca}}$ & $625.76 \pm 11.4^{\mathrm{Db}}$ & $515 \pm 47.1^{\mathrm{Ca}}$ & $487 \pm 12.8^{\mathrm{Ca}}$ \\
\hline$\%$ of change $e^{P 1}$ & (74.34) & (57.98) & $(106.66)$ & $(67.10)$ & $(61.90)$ \\
\hline $\mathrm{Vl}$ & $601.00 \pm 24.7^{\mathrm{Dc}}$ & $296.20 \pm 10.4^{\mathbf{A a}}$ & $294.09 \pm 34.13^{\text {Aa }}$ & $370.55 \pm 15.9^{\mathbf{A B b}}$ & $379.80 \pm 5.69^{\mathbf{B b}}$ \\
\hline$\%$ of change $e^{P 2}$ & $(11.93)$ & $(-37.96)$ & $(-53.00)$ & $(-28.05)$ & $(-22.01)$ \\
\hline
\end{tabular}

Data were expressed as a mean of 5 mice \pm standard error of the mean (SEM)

In rows (small letters) and columns (capital letters), values marked with the same small and capital superscript letters are similar (insignificant, $P \geq 0.05$ ) and are significant $(P<0.05)$, respectively. ${ }^{P 1, P 2}$ Percentage of change in comparison with the corresponding groups I and $V$, respectively 
Table 7 Plasma levels of $\mathrm{IL}-1 \beta(\mathrm{pg} / \mathrm{ml})$ in the experimental groups at the experimental periods

\begin{tabular}{|c|c|c|c|c|c|}
\hline \multirow{2}{*}{$\begin{array}{l}\text { Experimental } \\
\text { groups }\end{array}$} & \multicolumn{5}{|c|}{ Experimental periods (days) } \\
\hline & 3 & 10 & 17 & 24 & 31 \\
\hline I & $35.80 \pm 1.69^{\mathbf{A a}}$ & $39.00 \pm 2.79^{\mathbf{A a}}$ & $39.12 \pm 3.16^{\mathbf{A a}}$ & $33.00 \pm 1.14^{\mathbf{A a}}$ & $37.20 \pm 1.93^{\mathrm{Aa}}$ \\
\hline$\|$ & $40.60 \pm 2 . .^{\mathrm{ABa}}$ & $39.54 \pm .81^{\mathrm{Aa}}$ & $41.76 \pm .78^{\mathbf{A a}}$ & $38.40 \pm 2.09^{\mathrm{ABa}}$ & $38.20 \pm .97^{\mathrm{Aa}}$ \\
\hline$\%$ of change $\mathrm{P}^{\mathrm{P} 1}$ & $(13.41)$ & $(1.39)$ & $(6.75)$ & (16.36) & (2.69) \\
\hline III & $38.52 \pm 2.98^{\mathbf{A a}}$ & $44.60 \pm 4.97^{\mathrm{Aa}}$ & $40.20 \pm 7.61^{\mathrm{Aa}}$ & $40.80 \pm 2.42^{\mathrm{Ba}}$ & $36.68 \pm 3.3^{\mathrm{Aa}}$ \\
\hline$\%$ of change $\mathrm{e}^{\mathrm{P} 1}$ & $(7.60)$ & (14.36) & $(2.76)$ & (23.64) & $(-1.40)$ \\
\hline IV & $33.60 \pm 1.81^{\mathrm{Aa}}$ & $36.00 \pm 2.7^{\mathrm{Aa}}$ & $42.20 \pm 2.85^{\mathrm{Aa}}$ & $38.60 \pm 3.85^{\mathrm{ABa}}$ & $37.20 \pm 4.8^{\mathbf{A a}}$ \\
\hline$\%$ of change $\mathrm{e}^{\mathrm{P} 1}$ & $(-6.15)$ & $(-7.69)$ & $(7.87)$ & (16.97) & $(0.00)$ \\
\hline V & $48.20 \pm 2.71^{\mathrm{Ba}}$ & $71.60 \pm 1.9^{B C}$ & $56.80 \pm 1.69^{\mathbf{B b}}$ & $45.40 \pm 1.29^{\mathbf{B a}}$ & $51.20 \pm 2.2^{\text {Bab }}$ \\
\hline$\%$ of change $\mathrm{e}^{\mathrm{P} 1}$ & (34.64) & (83.59) & (45.19) & (37.58) & (37.63) \\
\hline $\mathrm{Vl}$ & $48.12 \pm 3.35^{\mathrm{Bb}}$ & $42.00 \pm 2.1^{\text {Aab }}$ & $43.80 \pm 2.04^{\mathbf{A b}}$ & $44.40 \pm 1.8^{\mathbf{B b}}$ & $35.40 \pm 3.53^{\mathrm{Aa}}$ \\
\hline$\%$ of change ${ }^{P 2}$ & $(-0.17)$ & $(-41.34)$ & $(-22.89)$ & $(-2.20)$ & $(-30.86)$ \\
\hline
\end{tabular}

Data were expressed as a mean of 5 mice \pm standard error of the mean (SEM)

In rows (small letters) and columns (capital letters), values marked with the same small and capital superscript letters are similar (insignificant, $P \geq 0.05)$ and are significant $(P<0.05)$, respectively. ${ }^{P 1, P 2}$ Percentage of change in comparison with the corresponding groups I and $\mathrm{V}$, respectively

1h, i). Most of the sections are normal, but some sections of mice administered with curcumin exhibited lymphoblast activation and hyperplasia (group IV) (Fig. 1j). In the sections of STZ diabetic mice, the lymphoid follicles were characterized by lymphocytic necrosis and lymphocyte depletion, and extramedullary megakaryocytosis was observed in some sections (group V) (Fig. $1 \mathrm{k}$ ). On the other hand, no histopathological changes were noticed in the splenic sections of STZ-induced diabetic mice treated with curcumin (group VI) (Fig. 11).

Insulin and phospho-NF-KB immunohistochemistry

Immunohistochemical staining of insulin is depicted in Fig. $2 \mathrm{a}-\mathrm{f}$. In groups I, II, and III, $\beta$ cells showed a brown immunostaining color, consistently disturbed within the pancreatic islets. Group IV showed pancreatic $\beta$ cells with positive brown immunostaining color. Group V showed an increase in the intensity of brown color. Group VI showed a decrease in the staining color of pancreatic $\beta$ cells.

The localization of phospho-NF- $\mathrm{kB}$ expression in the pancreatic sections in all studied groups is shown in Fig. $2 \mathrm{~g}-\mathrm{l}$. Most of the pancreatic sections of groups I, II, and III demonstrated a negative immunostaining brown color for phospho-NF- $k$ B. However, curcumin induced a slight increase in the expression of immunostaining brown color. Sections of the diabetic mice (group IV) showed the strongest positive phospho-NF-kB

Table 8 Plasma levels of IL-2 $(\mathrm{pg} / \mathrm{ml})$ in the experimental groups at the experimental periods

\begin{tabular}{|c|c|c|c|c|c|}
\hline \multirow{2}{*}{$\begin{array}{l}\text { Experimental } \\
\text { groups }\end{array}$} & \multicolumn{5}{|c|}{ Experimental periods (days) } \\
\hline & 3 & 10 & 17 & 24 & 31 \\
\hline I & $51.60 \pm 3.14^{\mathrm{BCa}}$ & $53.40 \pm 2.29^{\mathrm{BCa}}$ & $52.20 \pm 3.72^{\mathrm{Ba}}$ & $59.80 \pm 2.27^{\mathbf{B a}}$ & $59.00 \pm 1.87^{\mathrm{Ba}}$ \\
\hline$\|$ & $59.80 \pm 1.32^{\mathrm{Da}}$ & $60.40 \pm 2.1^{\mathrm{CDa}}$ & $57.80 \pm 2.62^{\mathrm{Ba}}$ & $53.80 \pm 7.44^{\mathrm{Ba}}$ & $58.00 \pm 2.39^{\mathrm{Ba}}$ \\
\hline$\%$ of change ${ }^{P 1}$ & $(15.89)$ & $(13.11)$ & $(10.73)$ & $(-10.03)$ & $(-1.70)$ \\
\hline III & $59.20 \pm 2.78^{\mathrm{CDa}}$ & $53.20 \pm 2.37^{\mathrm{BCa}}$ & $51.80 \pm 2.08^{\mathrm{Ba}}$ & $55.00 \pm 2.45^{\mathrm{Ba}}$ & $57.20 \pm 2.04^{\mathrm{Ba}}$ \\
\hline$\%$ of change $e^{P 1}$ & $(14.73)$ & $(-0.38)$ & $(-0.76)$ & $(-8.03)$ & $(-3.05)$ \\
\hline IV & $58.60 \pm 1.97^{\mathrm{CDa}}$ & $68.80 \pm 3.92^{\mathrm{Db}}$ & $55.20 \pm 2.08^{\mathbf{B a}}$ & $59.00 \pm 1.58^{\mathbf{B a}}$ & $59.20 \pm 2.9^{\mathbf{B a}}$ \\
\hline$\%$ of change ${ }^{P 1}$ & $(13.57)$ & $(28.84)$ & $(5.75)$ & $(-1.34)$ & $(0.34)$ \\
\hline V & $38.60 \pm 2.04^{\text {Aab }}$ & $35.60 \pm 2.11^{\mathrm{Aa}}$ & $38.20 \pm 2.2^{\text {Aab }}$ & $36.60 \pm 2.44^{\text {Aab }}$ & $42.80 \pm .86^{\mathbf{A b}}$ \\
\hline$\%$ of change $e^{P 1}$ & $(-25.19)$ & $(-33.33)$ & $(-26.82)$ & $(-38.80)$ & $(-27.50)$ \\
\hline $\mathrm{Vl}$ & $45.20 \pm 3.1^{\mathrm{ABa}}$ & $46.60 \pm 5.35^{\mathrm{Ba}}$ & $43.60 \pm 2.5^{\text {Aa }}$ & $52.60 \pm 4.49^{\mathbf{B a}}$ & $55.00 \pm 1.92^{\mathrm{Ba}}$ \\
\hline$\%$ of change $e^{P 2}$ & $(17.10)$ & $(30.90)$ & $(14.14)$ & (43.72) & $(28.51)$ \\
\hline
\end{tabular}

Data were expressed as a mean of 5 mice \pm standard error of the mean (SEM)

In rows (small letters) and columns (capital letters), values marked with the same small and capital superscript letters are similar (insignificant, $P \geq 0.05$ ) and are significant $(P<0.05)$, respectively. ${ }^{P 1, P 2}$ Percentage of change in comparison with the corresponding groups I and $V$, respectively 
Table 9 Plasma levels of IFN- $\gamma(\mathrm{pg} / \mathrm{ml})$ in the experimental groups at the experimental periods

\begin{tabular}{|c|c|c|c|c|c|}
\hline \multirow{2}{*}{$\begin{array}{l}\text { Experimental } \\
\text { groups }\end{array}$} & \multicolumn{5}{|c|}{ Experimental periods (days) } \\
\hline & 3 & 10 & 17 & 24 & 31 \\
\hline 1 & $125.40 \pm 10.73^{\mathbf{A a}}$ & $115.20 \pm 8.17^{\mathbf{A a}}$ & $142.80 \pm 14.07^{\mathbf{A B a}}$ & $144.00 \pm 7.49^{\mathbf{A B a}}$ & $140.80 \pm 7.04^{\mathrm{BCa}}$ \\
\hline$\|$ & $123.94 \pm 12.95^{\mathrm{Aa}}$ & $184.00 \pm 27.31^{\mathrm{BCb}}$ & $162.20 \pm 10.43^{\text {Bab }}$ & $150.40 \pm 15.48^{\text {Bab }}$ & $157.40 \pm 12.06^{\mathrm{Cab}}$ \\
\hline$\%$ of change ${ }^{\mathrm{P} 1}$ & $(-1.64)$ & $(-59.72)$ & $(-13.59)$ & $(-4.44)$ & $(-11.79)$ \\
\hline III & $121.40 \pm 29.83^{\mathrm{Aa}}$ & $156.00 \pm 13.9^{\mathbf{A B a}}$ & $164.6 \pm 12.21^{\mathrm{Ba}}$ & $148.60 \pm 9.56^{\mathbf{A B a}}$ & $145.20 \pm 6.87^{\mathrm{BCa}}$ \\
\hline$\%$ of change $e^{P 1}$ & $(-3.19)$ & $(-35.42)$ & $(-15.27)$ & $(-3.19)$ & $(-3.13)$ \\
\hline IV & $110.12 \pm 3.86^{\mathbf{A a}}$ & $138.00 \pm 3.56^{\mathbf{A b}}$ & $117.00 \pm 4.78^{\mathbf{A a}}$ & $132.40 \pm 7^{\mathbf{A B b}}$ & $115.60 \pm 5.34^{\mathrm{ABa}}$ \\
\hline$\%$ of change $e^{P 1}$ & $(-12.19)$ & $(-19.79)$ & $(-18.07)$ & $(-8.06)$ & $(-17.90)$ \\
\hline V & $226 \pm 22.27^{\mathbf{B b}}$ & $198.20 \pm 7.46^{\mathrm{Cab}}$ & $160 \pm 10.22^{\mathbf{B a}}$ & $166.60 \pm 16.31^{\mathrm{Ba}}$ & $204.60 \pm 19.2^{\text {Dab }}$ \\
\hline$\%$ of change $e^{P 1}$ & $(80.22)$ & (72.05) & $(12.05)$ & $(15.69)$ & $(45.31)$ \\
\hline $\mathrm{Vl}$ & $222.04 \pm 13.57^{\mathrm{ABC}}$ & $140.40 \pm 3.72^{\mathbf{A b}}$ & $119.00 \pm 3.32^{\mathbf{A a}}$ & $112.40 \pm 1.23^{\mathrm{Aa}}$ & $108 \pm 3.37^{\text {Aa }}$ \\
\hline$\%$ of change $e^{P 2}$ & $(-1.75)$ & $(-29.16)$ & $(-25.63)$ & $(-32.77)$ & $(-47.21)$ \\
\hline
\end{tabular}

Data were expressed as a mean of 5 mice \pm standard error of the mean (SEM)

In rows (small letters) and columns (capital letters), values marked with the same small and capital superscript letters are similar (insignificant, $P \geq 0.05)$ and are significant $(P<0.05)$, respectively. ${ }^{P 1, P 2}$ Percentage of change in comparison with the corresponding groups I and $\mathrm{V}$, respectively

immunostaining brown color (group V). Treatment of diabetic mice (group VI) with curcumin decreased the intensity of immunostaining brown color.

\section{Morphometric analysis of insulin and phospho-NF-KB expression}

Quantitative data for immunohistochemical morphometric analysis of pancreatic sections are illustrated in Fig. 3. The size of Langerhans islets in diabetic mice (group V) was quantitatively decreased as the area percentage of the islets was significantly $(P<0.01)$ reduced compared to normal mice. Treatment of diabetic mice (group VI) with curcumin improves the shrinkage in the size of Langerhans islets, whereas the area percentage was enlarged significantly $(P<0.05)$ compared to diabetic mice (Fig. 3a). Regarding $\beta$ cell evaluation in Langerhans islets, diabetic mice (group V) showed a significant $(P<$ $0.05)$ decrease in the area percentage of the $\beta$ cells compared to normal mice. Treatment of diabetic mice with curcumin provoked a significant elevation $(P<0.01)$ in the area percentage of $\beta$ cells compared to diabetic mice (Fig. 3b). The mean count of $\beta$ cells in the group of diabetic mice was significantly decreased $(P<0.01)$ compared to the normal group. On the other hand, the mean count of $\beta$ cells in the treated diabetic group was significantly increased $(P<0.001)$ compared to the diabetic group (Fig. 3c).

The protein expression of phospho-NF-кB-p65 in the pancreatic sections' immunostaining for the diabetic mice (group V) displayed a significant $(P<0.001)$ elevation in the area percentage and count $(P<0.01)$ of phospho-NFkB-p65 compared to the normal group. Treatment of diabetic mice with curcumin (group VI) suppressed significantly $(P<0.05)$ its area percentage and count $(P<$ 0.001) compared to the diabetic group (Fig. 3d, e), respectively.

\section{Discussion}

T1D is an autoimmune disease associated with several pathological changes in pancreatic islets. Diabetes induction is recognized in the mouse model by elevated blood glucose levels caused by damage to the pancreas structure (Takasu, Komiya, Asawa, Nagasawa, \& Yamada, 1991). Herein, diabetic mice exhibited significantly increased levels of glucose as compared to the control and vehicle-treated control. Treatment with curcumin caused a decrease in the blood glucose level of diabetic mice. These findings were consistent with El-Azab, Attia, and El-Mowafy (2011), who observed that glucose levels were decreased significantly with reverse hypoinsulinemia in STZ-induced diabetic mice treated with curcumin ( $10 \mathrm{mM} ; 100 \mu \mathrm{l} /$ mouse) for 28 days. Moreover, curcumin has been able to reduce the blood glucose levels in diabetic rat models with an oral dose of $60 \mathrm{mg} /$ $\mathrm{kg}$ body weight within 14 days (Peeyush, Gireesh, Jobin, \& Paulose, 2009) and $100 \mathrm{mg} / \mathrm{kg}$ per day for 7 weeks (Jain, Rains, Croad, Larson, \& Jones, 2009).

Autoimmune diabetes was related to the initial steps of inflammation; contact between macrophages and pancreatic $\beta$ cell triggered the recruitment of neutrophils (Huang, Xiao, Xu, \& Zhou, 2016). Generally, diabetes induction is usually associated with changes in the differential of WBCs. Some human studies (Moradi, Kerman, Rohani, \& Salari, 2012) and a rat model of STZ-induced diabetes (Moubarz, Embaby, Doleib, \& Taha, 2016) showed leukocytosis in the peripheral blood. Nevertheless, the current STZ-induced diabetic mice exhibited a persistent decline in the count of 


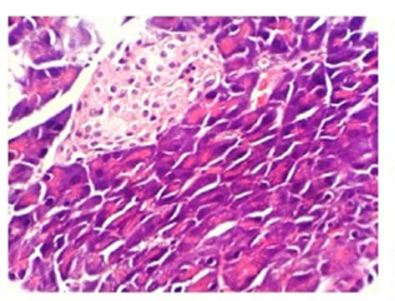

a) group I pancreas

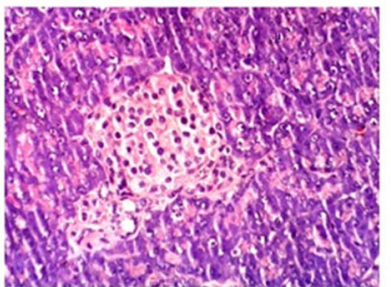

d) group IV pancreas

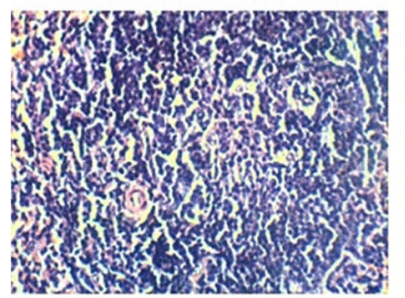

g) group I spleen

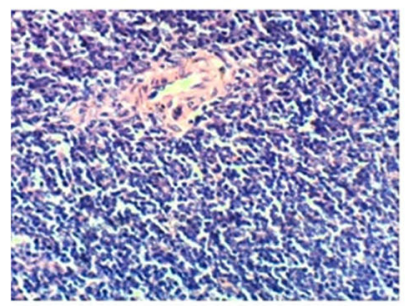

j) group IV spleen

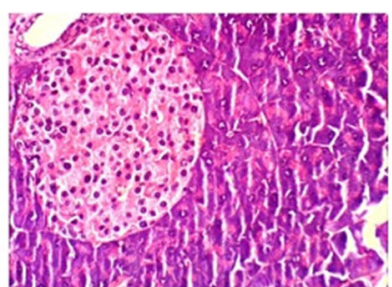

b) group II pancreas

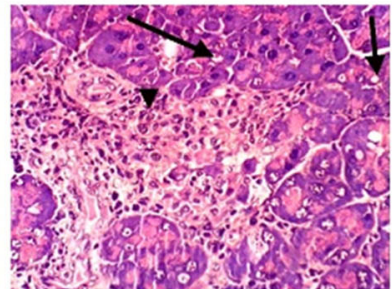

e) group $\mathrm{V}$ pancreas

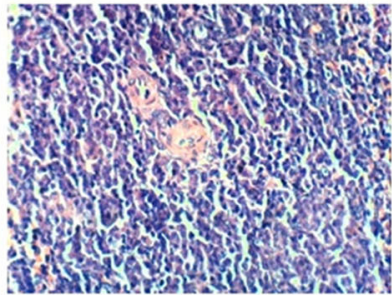

h) group II spleen

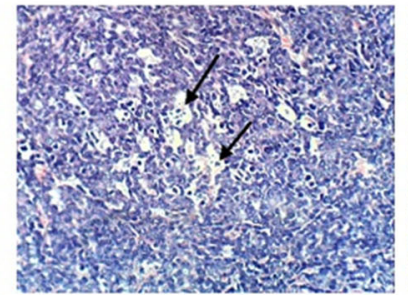

k) group V spleen

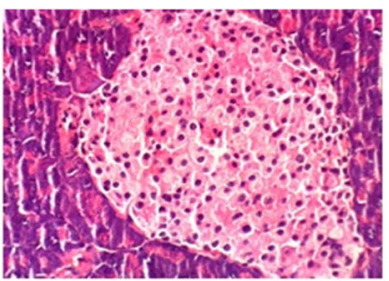

c) group III pancreas

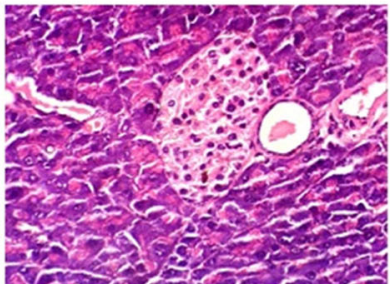

f) group VI pancreas

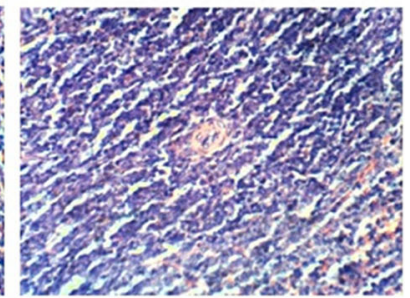

i) group III spleen

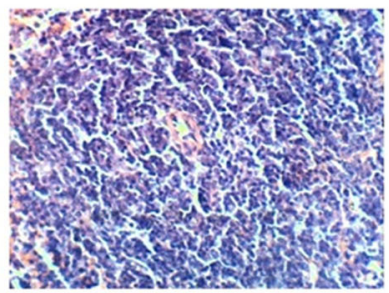

I) group VI spleen

Fig. 1 Histological evaluation of pancreatic islets $(\mathbf{a}-\mathbf{f})$ and spleen tissues $(\mathbf{g}-\mathbf{I})$ stained with hematoxylin and eosin dyes, $\times 400$ magnification. Pancreatic sections showed the following: a-d normal appearance of islets; e vacuolation of cells in pancreatic acini (small arrow), apoptosis of acinar epithelium (large arrow), and mononuclear inflammatory cells infiltration (arrowhead); $\mathbf{f}$ regular outline with normal appearance. Spleen sections showed the following: $\mathbf{g}-\mathbf{j}$ normal appearance of lymphoid follicles; $\mathbf{k}$ lymphocytic necrosis and depletion in the splenic lymphoid follicle (arrow); I normal appearance of splenic lymphoid follicles. I, normal mice; II, mice treated with citrate; III, mice treated with DMSO; IV, mice treated with curcumin at a dose of $170 \mathrm{mg} / \mathrm{kg}$ trice a week; $\mathrm{V}$, diabetic mice induced by injection with $160 \mathrm{mg} / \mathrm{kg}$ of STZ; and VI, diabetic mice treated with curcumin (170 $\mathrm{mg} / \mathrm{kg}$ trice a week)

leukocytes, lymphocytes, and monocytes, reaching and reporting significant differences on day 28 in comparison with the normal group. Such findings were consistent with several studies that find a low number of WBCs and mononuclear cells in diabetic mice (Bella et al., 2017). The peripheral blood of pediatric T1DM patients recorded a decrease in the number of lymphocytes (Gligor-dincă et al., 2015) and leucocytes (Klocperk et al., 2019). Furthermore, the populations of circulating monocytes have been shifted due to diabetes (Gonzalez et al., 2012). In the current research, curcumin administered to STZ-induced diabetic mice stimulated the increase of lymphocytes and monocytes count to normal values which were synergistic with a reduction in the granulocyte count. Curcumin therapy may therefore selectively inhibit the infiltration of leukocytes into the pancreas, which may inhibit the crosstalk between innate immune and $\beta$ cells (Huang et al., 2016).

Up until now, the implications of the true process of $\beta$ cell destruction have not been explained clearly. Directed immune cells towards the pancreatic islets produce various proinflammatory cytokines that trigger the infiltration of autoreactive $\mathrm{T}$ cells. Moreover, pancreatic $\beta$ cells can secrete some inflammatory cytokines that increase NO production and the initiation of apoptosis (Cnop et al., 2005). IL-6 is a pleiotropic cytokine that has a role in the regulation of both immune and 


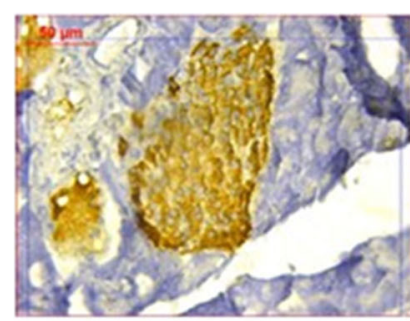

a) Group I insulin

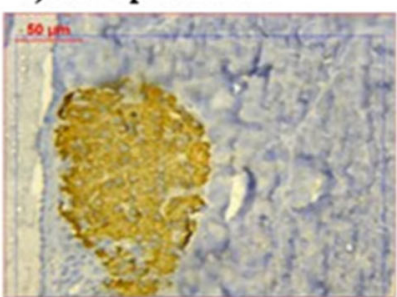

d) Group IV insulin

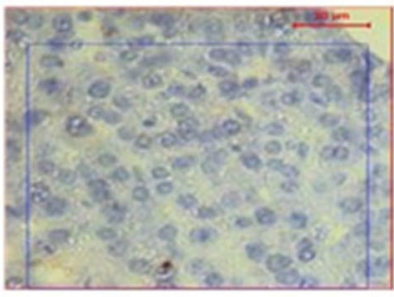

g) Group I p-NF-kB

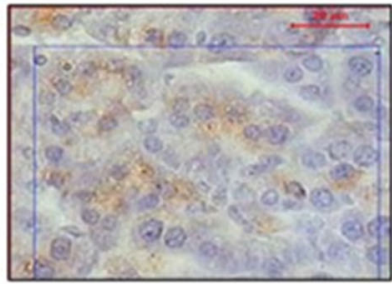

j) Group IV p-NF-kB

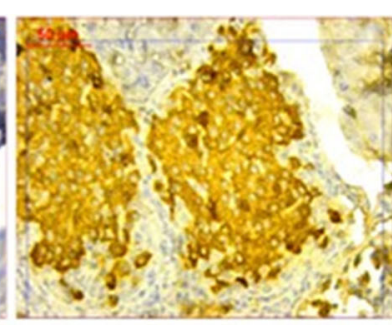

b) Group II insulin

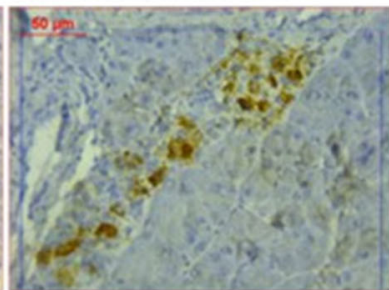

c) Group III insulin

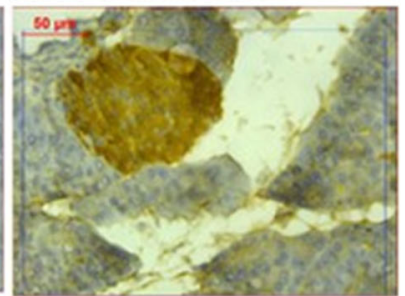

e) Group V insulin

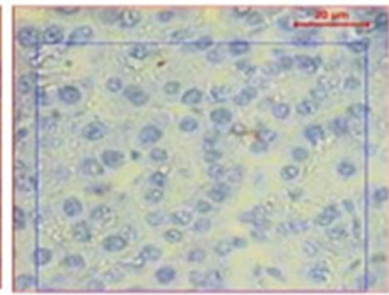

f) Group VI insulin

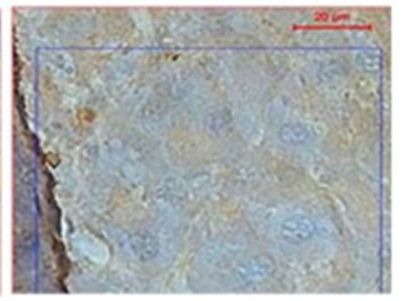

h) Group II p-NF-kB

i) Group III p-NF-kB

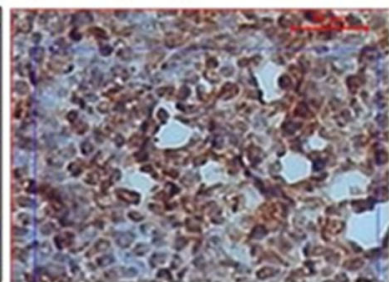

k) Group V p-NF-kB

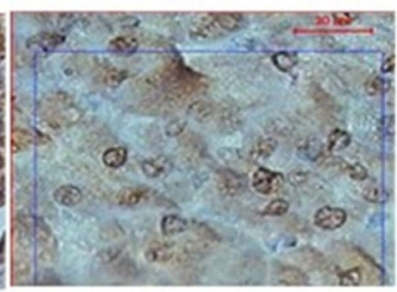

l) Group VI p-NF $-\mathbf{B}$

Fig. 2 Expression of insulin and phosphorylated-NF-KB by immunohistochemistry. Photomicrographs of pancreatic islets stained with positive brown color for anti-insulin (a-f) and anti-p-NF-kB antibodies ( $\mathbf{g}-\mathbf{I})$ in CD1 mice. Group I, normal mice; group II, mice treated with citrate; group III, mice treated with DMSO; group IV, mice treated with curcumin at a dose of $170 \mathrm{mg} / \mathrm{kg}$; group V, diabetic mice induced by injection with 160 $\mathrm{mg} / \mathrm{kg}$ of STZ; group VI, diabetic mice treated with curcumin with a dose of $170 \mathrm{mg} / \mathrm{kg}$. Magnification is $\times 400$. p-NF-KB, phosphorylated-NF-KB

nonimmune cells. Initially, it has proinflammatory and other effects on the immune responses. In the present study, the plasma levels of IL-6 in the diabetic mice recorded significantly higher levels $(P<0.05)$ than those in normal mice. Such findings are consistent with previous studies (Campbell, Kay, Oxbrow, \& Harrison, 1991) where IL-6 was expressed in immune cells-infiltrated pancreatic islets of NOD mice, which referred to the possible role of IL-6 in the pathogenic inflammation in the islets around $\operatorname{target} \beta$ cells. In the present study, the elevation of IL- 6 in the normal mice that were treated with curcumin may be attributed to the difference between immune-modulatory efficacy in case of disease condition and healthy state. In certain situations, IL-6 is modified to look like IL-10
(Yasukawa et al., 2003) which may result in a situation comparable to that in which an early development of IL-6 stimulates inflammation while sustained IL-6 levels can minimize inflammation (Hunter \& Jones, 2015).

IL- $1 \beta$ is another powerful proinflammatory cytokine that is secreted by blood monocytes, tissue macrophages, skin dendritic cells, and brain microglia in response to infection and injury. The current data revealed elevated plasma levels of IL-1 $\beta$ by diabetes initiation that is concordant with the observation of Fatima et al. (2016) that includes T1D patients. Thomas et al. (2004) revealed a $30 \%$ reduction of DM in the NOD mouse model with a knockout of the IL-1 receptor gene. IL-1 initiates T cell polarization towards proinflammatory state through 

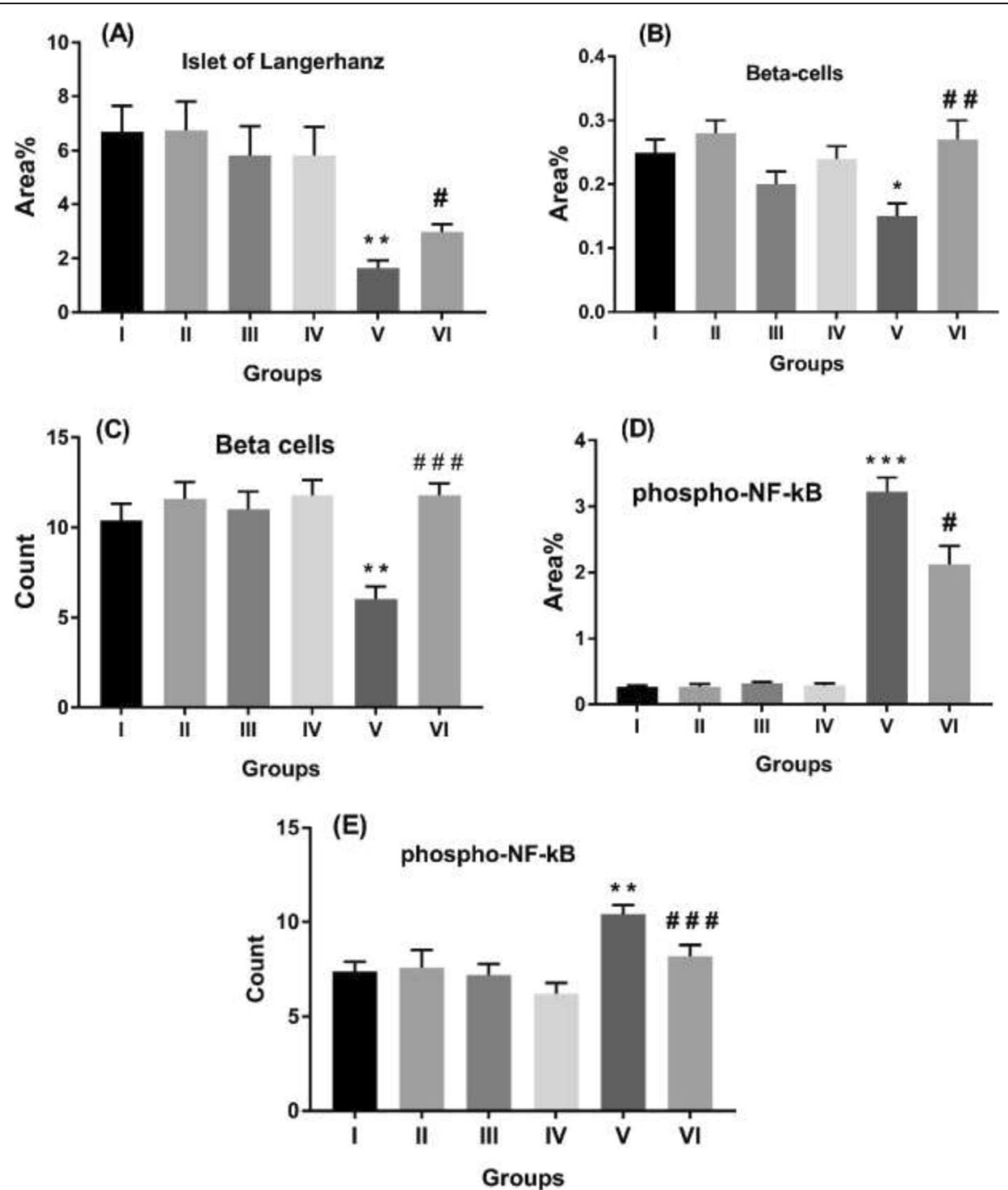

Fig. 3 Immunostaining expression of insulin and phospho-NF-KB-p65 in pancreatic sections. For insulin (a-c), area percentage of Langerhans islets (a), area percentage of $\beta$ cells (b), and count of $\beta$ cells (c). For phospho-NF-kB (d and $\mathbf{e}$ ), area percentage (d) and count (e). Data were expressed as mean \pm (SEM). Significantly ${ }^{*} P<0.05$, ${ }^{*} P<0.01$, and ${ }^{* * *} P<0.001$ ) compared to normal mice (group I). Significantly $\left({ }^{\#} P<0.05\right.$, ${ }^{\# \#} P$ $<0.01$, and ${ }^{\# \# \# P<0.001)}$ compared to diabetic mice (group V). Normal mice (group I). Mice treated with citrate (group II), DEMSO (group III), or curcumin (170 mg/kg) (group IV). Diabetic mice induced by STZ (160 mg/kg) (group V). Diabetic mice treated with curcumin (170 mg/kg) (group VI). p-NF-KB, phosphorylated-NF-KB; DMSO, dimethylsulfoxide

activation of Th1, Th17 cells, or antibody production via a Th2 bias. Different immune and pancreatic islet cells have initiated proinflammatory signaling which collectively takes part in $\beta$ cell death, as directed by master IL-1 $\beta$ in both T1D and T2D. Another study by Osborn et al. (2008) stated that the increased IL$1 \beta$ levels are accompanied by impaired insulin secretion, decreased cell proliferation, and apoptosis of pancreatic $\beta$ cells. Moreover, the proinflammatory cytokines like IL- $1 \beta$ and IL- 6 were secreted by monocytes that were isolated directly from the blood of T1D patients (Bradshaw et al., 2009).
IL-2 is one of the fundamental $\mathrm{CD} 4^{+} \mathrm{Th} 1$ cell-related cytokines that present helper function for $\mathrm{CD}^{+}$cytotoxic $\mathrm{T}$ cells. It is a growth factor for $\beta$ cells and involved in the regulation of innate lymphoid cells and antibody synthesis. $\mathrm{T}$ regulatory (Treg) cells are highly dependent on IL-2 for survival, and a lower level of IL-2 is observed in autoimmune diseases due to impairment in Treg function (Spence \& Tang, 2016). In the current STZ diabetic mice, the level of IL-2 was suppressed during all experimental. These results are in good agreement with other studies which have shown a reduced production of IL-2 by lymphocytes stimulated with 
mitogen (PHA) in T1D patients (Giordano et al., 1993). Several studies have emphasized the function of exogenous IL-2 and protection against diabetes induction in NOD mice (Grinberg-Bleyer et al., 2010).

Under certain conditions, IFN- $\gamma$ is produced by Th1 CD4+ T cells, CD8+ T cells, and natural killer cells during viral infections. Among several activities of IFN- $\gamma$, it is announced to inhibit the proliferation of Th2 cells and to promote switching of Ig class to IgG2a secretion (Bhat, Leggatt, Waterhouse, \& Frazer, 2017). Upon induction of diabetes in the current work, the levels of IFN- $\gamma$ were significantly increased compared to normal mice, recorded the highest percentage of $80 \%$ at the early stage. These results highlight evidence of the pronounced impact of IFN- $\gamma$ production on the $\beta$ cell destruction pathway. The association has been reported by Katz, Benoist, and Mathis (1995) who have demonstrated that diabetes is rapidly induced in neonatal NOD mice after transfer of Th1-like cells in almost all recipients. The presence of $\mathrm{T}$ lymphocytes producing IFN- $\gamma$ in the islet of Langerhans is considered as an early feature of the disease process in diabetic patients (Foulis, McGill, \& Farquharson, 1991) and NOD mice (Kaufman et al., 1993; Rothe et al., 1994). Furthermore, in T1D patients with glucose levels above $160 \mathrm{mg} / \mathrm{dl}, \mathrm{IFN}-\gamma$ and TNF- $\alpha$ expression were significantly upregulated (Fatima et al., 2016). Both IFN- $\gamma$ and IL-1 $\beta$ have a bad impact on the viability of pancreatic $\beta$ cells by allowing the translocation of NF-KB (Csorba et al., 2010).

In the context of anti-inflammatory activities of curcumin, several studies suggested possible mechanisms where curcumin has inhibitory effects on the functions of $\mathrm{T}$ and $\mathrm{B}$ lymphocytes, macrophages proliferation, and antibody production (IgG1 and IgG2a) (Sharma, Steward, \& Gescher, 2007). Jain and coworkers found that curcumin has a preferential suppressing effect on the secretion of IL- 6 , TNF- $\alpha$, IL-8, and MCP-1 in cultured U937 monocytes with high glucose $(35 \mathrm{mM})$ and blood levels of STZ diabetic rat model (Jain et al., 2009).

Several studies support the proposed properties of curcumin to suppress the generation of proinflammatory cytokines by inhibiting degradation of IKB $\alpha$ and a decrease of NF- $\mathrm{kB}$ translocation, which is useful in reducing macrophage infiltration, and preventing TNF- $\alpha$ and IL- $1 \beta$ from release in diabetic nephropathy (Soetikno et al., 2011) and a decrease in TNF- $\alpha$ and IL- $1 \beta$, and IFN- $\gamma$ concentrations in vitro (Kanitkar, Gokhale, Galande, \& Bhonde, 2008). The pattern of cytokines in the present diabetic mice was altered after curcumin administration to be lower levels of IFN- $\gamma$, IL- 6 , and IL- $\beta$, as well as higher levels of IL-2. This specific pattern might regard to its influence on the different mechanism pathways. Activation of NF-kB paves the pathway for further reinforcement of inflammatory responses by stimulating the transcription of a vast array of inflammatory mediators linked to the recruitment of leukocytes and secretion of cytokines (Lawrence, 2009). Under the influence of IL-1 $\beta$ and IFN- $\gamma$, non-canonical NF- $\mathrm{BB}$ pathway activationgenerated mechanisms lead to apoptotic features of $\beta$ cells (Meyerovich et al., 2016).

In T1D, the production of IL- $1 \beta$ activates NF- $\kappa B$ that shared immune responses associated with pancreatic $\beta$ cells dysfunction and death (Patel \& Santani, 2009). The present work revealed a marked intensity of the phospho-NF- $k B$ expression in the pancreatic sections of STZ-induced diabetic mice compared to normal pancreatic sections. Moreover, defined $\beta$ cell activation of NF$\mathrm{kB}$ is a vital consequence in the continuing loss of $\beta$ cells in multiple low-dose STZ-induced diabetes (Eldor et al., 2006). The present diabetic mice treated with curcumin displayed an obvious reduction in the intensity of phospho-NF- $\kappa \mathrm{B}$ immunostaining that is comparable with Castro et al. (2014) who revealed that curcumin suppressed the NF- $\mathrm{BB}$ activation in $\mathrm{T}$ cell receptorstimulated $\mathrm{T}$ lymphocytes of NOD mice (Castro et al., 2014). Subsequently, curcumin downregulates the gene expression of proinflammatory cytokines including TNF$\alpha$, IL-1, and IL-6 (Cho, Lee, \& Kim, 2007; Ghandadi \& Sahebkar, 2017).

The damage caused by STZ administration varied from necrotic to apoptotic features of pancreatic $\beta$ cells (Daisy, Rashmi, Akila, \& Gunasekaran, 2004). The $\beta$ cell apoptosis is linked to the inflammation in STZ diabetic rats (Rashid \& Sil, 2015). In the present study, the histological evaluation showed a disruption in the general morphology of the pancreatic islets that accompanied diabetic mice, leading to a reduction in insulin-secreting pancreatic $\beta$ cells (Matveyenko \& Butler, 2008). Normally, $60-80 \%$ of murine $\beta$ cells were concentrated in the core of the pancreatic islets, while $15-20 \%$ of $\alpha$ cells found in the periphery of the islets (Steiner, Kim, Miller, \& Hara, 2010). The current research indicates a decline in the count of lymphocytes in the blood of STZinduced diabetic mice as well as the lymphocytic necrosis and depletion that may match with lymphopenia (Muller et al., 2011) and human diabetes in the peripheral lymphoid bodies (O'Kell et al., 2017).

Herein, the morphometric analysis demonstrated a marked decrease in the area percent of Langerhans islets and $\beta$ cells, as well as the count of $\beta$ cells in diabetic mice. These findings are well-known to other studies showing a rise in the islet shrinkage during disease length (Novikova et al., 2013), as well as a decrease in area and numbers in $\beta$ cells following the initiation of disease in T1D patients (Keenan et al., 2010). The supposed explanation for this decline is that $\beta$ cell destruction contributes to shrinking islets and a drop in pancreatic islet numbers (Chanpoo, Petchpiboonthai, 
Panyarachun, \& Anupunpisit, 2010). Curcumin administration caused an improvement to pancreatic islets in the present study that appeared as an increase in the area percentage of both pancreatic islets and $\beta$ cells compared to diabetic mice. Also, the substantial increase in the count of $\beta$ cells following curcumin was prominent. Such ability of curcumin to recover $\beta$ cell function and regeneration of new cells is comparable with other studies that showed neogenesis of islets in diabetic mice following 12 weeks of curcumin administration (Chanpoo et al., 2010) and an increase in the number of $\beta$ cells (Walvekar, Potphode, Desai, \& Deshmukh, 2016).

\section{Conclusion}

The current study demonstrates the useful role of curcu$\mathrm{min}$ in the progressive degradation of $\beta$ cells in diabetes caused by STZ. Curcumin exerted a lowering impact on the blood glucose level and granulocyte count. Its immunoregulatory activity is supported by low levels of IFN $-\gamma$, IL-6, and IL-1 $\beta$ as well as high levels of IL-2. Curcumin inhibits the NF- $\mathrm{KB}$ signaling pathway that may explain the importance of these proinflammatory cytokines in the pathogenesis of T1D. Moreover, it enhances the improvement of $\beta$ cell-specific apoptotic death by regeneration of pancreatic $\beta$ cells. Thereby, further studies needed to investigate the molecular mechanisms of curcumin-mediated $\beta$ cell regeneration.

\section{Abbreviations \\ DMSO: Dimethylsulfoxide; ELISA: Enzyme-linked immunosorbent assay; H\&E: Hematoxylin and eosin; HRP: Horseradish peroxidase; IFN: Interferon; IL: Interleukin; mAb: Monoclonal antibody; phosphor: Phosphorylated-NF- kBp65; STZ: Streptozotocin; T1D: Type 1 diabetes; Th: T helper; WBCs: White blood cells}

\section{Acknowledgements}

We would like to thank Prof. Dr. Koukap at the Faculty of Veterinary Medicine, Cairo University, as well as Dr. Marwa Shabna at the Pathology Department, National Research Center, very much for their support and advise in the histological examination.

\section{Authors' contributions \\ Abeer M. B. is responsible for the study design and planning, acquisition and analysis, and mainly writing of the manuscript. Howida S. contributed to the practical work and analysis and drafted the manuscript. Alyaa A.F. and Somaya E. contributed to the conception and design, acquisition, and analysis and drafted the manuscript. The authors read and approved the final manuscript.}

\section{Funding}

The authors received no financial support for the research.

\section{Availability of data and materials}

All data and materials presented in the manuscript are original work of the authors. The authors can be contacted for any additional supporting data required by the journal.

\section{Ethics approval and consent to participate}

Ethical approval for animal use is available.

\section{Consent for publication}

All authors gave final approval and agree to be accountable for all aspects of work ensuring integrity and accuracy.

\section{Competing interests}

The authors declare that they have no competing interest.

Received: 11 August 2019 Accepted: 30 March 2020

Published online: 13 May 2020

\section{References}

Aldahmash, B. A., El-Nagar, D. M., \& Ibrahim, K. E. (2016). Attenuation of hepatotoxicity and oxidative stress in diabetes STZ-induced type 1 by biotin in Swiss albino mice. Saudi J Biol Sci., 23(2), 311-317.

Bella, L.M., Fieri, I., Tessaro, F.H.G., Nolasco, E.L., Nunes, F.P.B., Ferreira, S.S., Azevedo, C.B., Martins, J.O., 2017. Vitamin D modulates hematological parameters and cell migration into peritoneal and pulmonary cavities in alloxan-diabetic mice. BioMed Research International, 7651815.

Bhat, P., Leggatt, G., Waterhouse, N., \& Frazer, I. H. (2017). Interferon- $\gamma$ derived from cytotoxic lymphocytes directly enhances their motility and cytotoxicity. Cell Death \& Disease, 8(6), e2836.

Blaslov, K. (2017). Curcumin - a polyphenol with molecular targets for diabetes control? Endocrine Oncology and Metabolism 2, 3(2), 43-48.

Bradshaw, E. M., Raddassi, K., Elyaman, W., Orban, T., Gottlieb, P. A., Kent, S. C., \& Hafler, D. A. (2009). Monocytes from patients with type 1 diabetes spontaneously secrete proinflammatory cytokines inducing Th17 cells. Journal of Immunology, 183(7), 4432-4439.

Campbell, I. L., Kay, T. W. H., Oxbrow, L., \& Harrison, L. C. (1991). Essential role for interferon- $\gamma$ and interleukin- 6 in autoimmune insulin-dependent diabetes in NOD/wehi mice. Journal of Clinical Investigation, 87(2), 739-742.

Castro, C. N., Barcala Tabarrozzi, A. E., Winnewisser, J., Gimeno, M. L., Antunica Noguerol, M., Liberman, A. C.., ... Perone, M. J. (2014). Curcumin ameliorates autoimmune diabetes. Evidence in accelerated murine models of type 1 diabetes. Clinical and Experimental Immunology, 177(1), 149-160.

Chanpoo, M., Petchpiboonthai, H., Panyarachun, B., \& Anupunpisit, V. (2010). Effect of curcumin in the amelioration of pancreatic islets in streptozotocininduced diabetic mice. Journal of the Medical Association of Thailand, 93(Suppl. 6), S152-S159.

Cho, J. W., Lee, K. S., \& Kim, C. W. (2007). Curcumin attenuates the expression of IL-1 beta, IL-6, and TNF-a as well as cyclin E in TNF-alpha-treated HaCaT cells; $\mathrm{NF}-\mathrm{KB}$ and MAPKs as potential upstream targets. International Journal of Molecular Medicine, 19, 469-474.

Cnop, M., Welsh, N., Jonas, J. C., Jörns, A., Lenzen, S., \& Eizirik, D. L. (2005). Mechanisms of pancreatic $\beta$-cell death in type 1 and type 2 diabetes: many differences, few similarities. Diabetes, 54(Supp2), S97-S107.

Csorba, T. R., Lyon, A. W., \& Hollenberg, M. D. (2010). Autoimmunity and the pathogenesis of type 1 diabetes. Critical Reviews in Clinical Laboratory Sciences, 47, 51-71.

Daisy, M., Rashmi, V., Akila, G., \& Gunasekaran, S. (2004). Effect of streptozotocin on the ultrastructure of rat pancreatic islets. Microscopy Research and Technique, 63, 274-281.

Deeds, M. C., Anderson, J. M., Armstrong, A. S., Gastineau, D. A., Hiddinga, H. J., Jahangir, A., ... Kudva, Y. C. (2011). Single dose streptozotocin-induced diabetes: considerations for study design in islet transplantation models. Laboratory Animals, 45(3), 131-140.

Eizirik, D.L., Colli, M.L., Ortis, F., 2009. The role of inflammation in insulitis and beta-cell loss in type 1 diabetes. Nature Reviews Endocrinology, 5,219-226. [PubMed: 19352320]

El-Azab, M. F., Attia, F. M., \& El-Mowafy, A. M. (2011). Novel role of curcumin combined with bone marrow transplantation in reversing experimental diabetes: effects on pancreatic islet regeneration, oxidative stress, and inflammatory cytokines. European Journal of Pharmacology, 658(1), 41-48.

Eldor, R., Yeffet, A., Baum, K., Doviner, V., Amar, D., Ben-Neriah, Y., ... Melloul, D. (2006). Conditional and specific NF-kappaB blockade protects pancreatic beta cells from diabetogenic agents. Proceedings of the National Academy of Sciences of the United States of America, 103(13), 5072-5077.

Fatima, N., Faisal, S.M., Zubair, S., Ajmal, M., Siddiqui, S.S., Moin, S., ... Owais, M., 2016. Role of pro-inflammatory cytokines and biochemical markers in the pathogenesis of type 1 diabetes: correlation with age and glycemic condition in diabetic human subjects. PLoS One, $11(8)$, e0161548.10.1371/ journal.pone.0161548.

Foulis, A. K., McGill, M., \& Farquharson, M. A. (1991). Insulitis in type 1 (insulindependent) diabetes mellitus in man-macrophages, lymphocytes, and interferon-gamma containing cells. The Journal of Pathology, 165, 97-103. 
Ghandadi, M., \& Sahebkar, A. (2017). Curcumin: an effective inhibitor of interleukin 6. Current Pharmaceutical Design, 23(6), 921-931.

Giordano, C., De Maria, R., Todaro, M., Stassi, G., Mattina, A., Richiusa, P., .. Galluzzo, A. (1993). Study of T-cell activation in type I diabetic patients and pre-type I diabetic subjects by cytometric analysis: antigen expression defect in vitro. The Journal of Clinical Immunology, 13, 68-78.

Gligor-dincă, F. S., Gligor, R., Lazăr-leordean, V., Petrine mocanu, C., Zdremțan, D., \& Puşchiță, M. (2015). Lymphocytes values in type 1 diabetes mellitus newly diagnosed in children. Proceedings of the Romanian Academy, Series B., 17(3), 229-232.

Gonzalez, Y., Herrera, M. T., Soldevila, G., Garcia-Garcia, L., Fabián, G., PérezArmendariz, E. M., ... Torres, M. (2012). High glucose concentrations induce TNF-alpha production through the down-regulation of CD33 in primary human monocytes. BMC Immunology, 13, 19.

Grinberg-Bleyer, Y., Baeyens, A., You, S., Elhage, R., Fourcade, G., Gregoire, S., .. Piaggio, E. (2010). IL-2 reverses established type1 diabetes in NOD mice by a local effect on pancreatic regulatory T cells. Journal of Experimental Medicine, 207, 1871-1878 https://doi.org/10.1084/jem.20100209PMID:20679400.

Grynkiewicz, G., \& Ślifirski, P. (2012). Curcumin and curcuminoids in quest for medicinal status. Acta Biochimica Polonica, 59, 201-212.

Huang, J., Xiao, Y., Xu, A., \& Zhou, Z. (2016). Neutrophils in type 1 diabetes. Journal of Diabetes Investigation, 7(5), 652-663. https://doi.org/10.1111/jdi. 12469.

Hunter, C. A., \& Jones, S. A. (2015). IL-6 as a keystone cytokine in health and disease. Nature Immunology, 16(5), 448-457.

Jain, S. K., Rains, J., Croad, J., Larson, B., \& Jones, K. (2009). Curcumin supplementation lowers TNF-alpha, LL-6, IL-8, and MCP-1 secretion in high glucose-treated cultured monocytes and blood levels of TNF alpha, IL-6, MCP-1, glucose, and glycosylated hemoglobin in diabetic rats. Antioxidants \& Redox Signaling, 11, 241-249.

Kahkhaie, K. R., Mirhosseini, A., Aliabadi, A., Mohammadi, A., Mousavi, M. J., Haftcheshmeh, S. M., ... Sahebkar, A. (2019). Curcumin: a modulator of inflammatory signaling pathways in the immune system. Inflammopharmacology, 27(5), 885-900.

Kanitkar, M., Gokhale, K., Galande, S., \& Bhonde, R. R. (2008). Novel role of curcumin in the prevention of cytokine-induced islet death in vitro and diabetogenesis in vivo. British Journal of Pharmacology, 155, 702-713.

Karfowicz-bodalska, K., Han, S., Freier, J., Smole-ski, M., \& Bodalska, A. (2017). Curcuma longa as medicinal herb in the treatment of diabetic complications. Acta Poloniae Pharmaceutica ñ Drug Research, 74(2), 605-610.

Katz, J. D., Benoist, C., \& Mathis, D. (1995). Thelper cell subsets in insulindependent diabetes. Science, 268, 1185-1188.

Kaufman, D. L., Clare-Salzler, M., Tian, J., Forsthuber, T., Ting, G. S., Robinson, P., ... Lehmann, P. V. (1993). Spontaneous loss of T-cell tolerance to glutamic acid decarboxylase in murine insulin-dependent diabetes. Nature, 366(6450), 69-72.

Kaul, K., Apostolopoulou, M., Roden, M., 2015. Insulin resistance in type 1 diabetes mellitus. Metabolism, 64(12), 1629-39.

Kazazis, C.h., G. Vallianou, N., Kollas, A., \& Evangelopoulos, A. (2014). Curcumin and diabetes: mechanisms of action and its anti-diabetic properties. Current topics in nutraceutical research, 12(4), 135-142.

Keenan, H. A., Sun, J. K., Levine, J., Doria, A., Aiello, L. P., Eisenbarth, G., ... King, G. L. (2010). Residual insulin production and pancreatic $\beta$-cell turnover after 50 years of diabetes: Joslin Medalist Study. Diabetes, 59(11), 2846-2853.

Klocperk A., Petruzelkova L., Pavlikova M., Rataj M., Kayserova J., Pruhova S., ... Kolouskova S., Sklenarova J., Parackova Z., Sediva A., Sumnik Z., 2019. Changes in innate and adaptive immunity over the first year after the onset of type 1 diabetes. Acta Diabetol. Sep 30.

Lawrence, T. (2009). The nuclear factor NF-KB pathway in inflammation. Cold Spring Harbor Perspectives in Biology, 1(6), a001651.

Matveyenko, A.V. and Butler, P.C., 2008. Relationship between beta-cell mass and diabetes onset. Diabetes, Obesity and Metabolism, 10 Suppl 4,23-31.

Meng, B.o., Li, J., \& Cao, H. (2013). Antioxidant and anti-inflammatory activities of curcumin on diabetes mellitus and its complications. Current Pharmaceutical Design, 19, 2101-2113.

Meyerovich, K., Fukaya, M., Terra, L. F., Ortis, F., Eizirik, D. L., \& Cardozo, A. K. (2016). The non-canonical NF-KB pathway is induced by cytokines in pancreatic beta cells and contributes to cell death and proinflammatory responses in vitro. Diabetologia, 59, 512-521.

Moradi, S., Kerman, S. R., Rohani, F., \& Salari, F. (2012). Association between diabetes complications and leukocyte counts in Iranian patients. Journal of Inflammation Research, 5, 7-11. https://doi.org/10.2147/JIR.S26917.
Moubarz, G., Embaby, M. A., Doleib, N. M., \& Taha, M. M. (2016). Effect of dietary antioxidant supplementation (Cuminum cyminum) on bacterial susceptibility of diabetes-induced rats. Central European Journal of Immunology, 41, 132137.

Muller, Y. D., Golshayan, D., Ehirchiou, D., Wyss, J. C., Giovannoni, L., Meier, R., et al. (2011). Immunosuppressive effects of streptozotocin-induced diabetes result in absolute lymphopenia and a relative increase of T regulatory cells. Diabetes, 60(9), 2331-2340.

Novikova, L., Smirnova, I. V., Rawal, S., Dotson, A. L., Benedict, S. H., \& StehnoBittel, L. (2013). Variations in rodent models of type 1 diabetes: islet morphology. Journal Diabetes Research, 965832.

O'Kell, A. L., Wasserfall, C., Catchpole, B., Davison, L. J., Hess, R. S., Kushner, J. A.r. ... Atkinson, M. A. (2017). Comparative pathogenesis of autoimmune diabetes in humans, NOD mice, and canines: has a valuable animal model of type 1 diabetes been overlooked? Diabetes, 66(6), 1443-1452.

Okazaki, T., Sakon, S., Sasazuki, T., Sakurai, H., Doi, T., Yagita, H., ... Nakano, H. (2003). Phosphorylation of serine 276 is essential for p65 NF-kappaB subunitdependent cellular responses. Biochemical and Biophysical Research Communications, 300, 807-812.

Osborn, O., Brownell, S. E., Sanchez-Alavez, M., Salomon, D., Gram, H., \& Bartfai, T. (2008). Treatment with an interleukin 1 beta antibody improves glycemic control in diet-induced obesity. Cytokine, 44(1), 141-148.

Patel, S., \& Santani, D. (2009). Role of NF-KB in the pathogenesis of diabetes and its associated complications. Pharmacological Reports, 61, 595-603.

Peeyush, K. T., Gireesh, G., Jobin, M., \& Paulose, C. S. (2009). Neuroprotective role of curcumin in the cerebellumof streptozotocin induced diabetic rats. Life Sciences, 85(19-20), 704-710.

Pirot, P., Cardozo, A. K., \& Eizirik, D. L. (2008). Mediators and mechanisms of pancreatic beta-cell death in type 1 diabetes. Arquivos Brasileiros de Endocrinologia e Metabologia, 52(2), 156-165.

Rashid, K., \& Sil, P. C. (2015). Curcumin enhances recovery of pancreatic islets from cellular stress induced inflammation and apoptosis in diabetic rats. Toxicology and Applied Pharmacology, 282, 297-310.

Rojas, J., Bermudez, V., Palmar, J., Martínez, M. S., Olivar, L. C., Nava, M., ... Velasco, M. (2018). Pancreatic beta cell death: novel potential mechanisms in diabetes therapy. Journal Diabetes Research, 2018, 9601801.

Rothe, H., Faust, A., Schade, U., Kleemann, R., Bosse, G., Hibino, T., ... Kolb, H. (1994). Cyclophosphamide treatment of female non-obese diabetic mice causes enhanced expression of inducible nitric oxide synthase and interferon-gamma, but not of interleukin-4. Diabetologia, 37, 1154-1158.

Sharma, R. A., Steward, W. P., \& Gescher, A. J. (2007). Pharmacokinetics and pharmacodynamics of curcumin. Advances in Experimental Medicine and Biology, 595, 453-470.

Soetikno, V., Sari, F. R., Veeraveedu, P. T., Thandavarayan, R. A., Harima, M. Sukumaran, V., ... Watanabe, K. (2011). Curcumin ameliorates macrophage infiltration by inhibiting NF-KB activation and proinflammatory cytokines in streptozotocin induced-diabetic nephropathy. Nutrition and Metabolism, 8(1), 35. https://doi.org/10.1186/1743-7075-8-35.

Spence, A., Tang, Q., 2016. Restoring regulatory T cells in type 1 diabetes. Current Diabetes Reports, 16(11):110... 100(11), 2288-2300. PMID: 27490409

Steiner, D. J., Kim, A., Miller, K., \& Hara, M. (2010). Pancreatic islet plasticity: interspecies comparison of islet architecture and composition. Islets, 2, 135-145.

Sun, C., Li, X., Liu, L., Canet, M. J., Guan, Y., Fan, Y., ... Zhou, Y. (2016). Effect of fasting time on measuring mouse blood glucose level. International Journal of Clinical and Experimental Medicine, 9(2), 4186-4189.

Takasu, N., Komiya, I., Asawa, T., Nagasawa, Y., \& Yamada, T. (1991). Streptozocinand alloxan-induced $\mathrm{H} 2 \mathrm{O} 2$ generation and DNA fragmentation in pancreatic islets: $\mathrm{H} 2 \mathrm{O} 2$ as mediator for DNA fragmentation. Diabetes, 40, 1141-1145.

Tamaddonfard, E., Erfanparast, A., Hamzeh-Gooshchi, N., \& Yousofizadeh, S. (2012). Effect of curcumin, the active constituent of turmeric, on penicillin-induced epileptiform activity in rats. Avicenna J Phytomed., 2(4), 196-205.

Thomas, H. E., Irawaty, W., Darwiche, R., Brodnicki, T. C., Santamaria, P., Allison, J., ... Kay, T. W. (2004). IL-1 receptor deficiency slows progression to diabetes in the NOD mouse. Diabetes, 53(1), 113-121.

Tosone, G., Maraolo, A. E., Palmiero, G., Mascolo, S., \& Orlando, R. (2013). Diabetes mellitus type 1, latent autoimmune diabetes of adults and hepatitis $C$ virus: what we know and what we need to know. Journal of Diabetes \& Metabolism, 4(8), 301-305.

Tremblay, J., \& Hamet, P. (2019). Environmental and genetic contributions to diabetes. Metabolism, 100S, 153952. 
Walvekar, M. V., Potphode, N. D., Desai, S. S., \& Deshmukh, V. M. (2016). Histological studies on islets of Langerhans of pancreas in diabetic mice after curcumin administration. International Journal of Pharmaceutical and Clinical Research, 8(9), 1314-1318.

Yasukawa, H., Ohishi, M., Mori, H., Murakami, M., Chinen, T., Aki, D., ... Yoshimura, A. (2003). IL-6 induces an anti-inflammatory response in the absence of SOCS3 in macrophages. Nature Immunology, 4, 551-556.

\section{Publisher's Note}

Springer Nature remains neutral with regard to jurisdictional claims in published maps and institutional affiliations.

\section{Submit your manuscript to a SpringerOpen ${ }^{\circ}$ journal and benefit from:}

- Convenient online submission

- Rigorous peer review

- Open access: articles freely available online

- High visibility within the field

- Retaining the copyright to your article

Submit your next manuscript at $\boldsymbol{\nabla}$ springeropen.com 